Emilio Bouza 1,2,3,4

Francisco José Brenes ${ }^{5}$

Javier Diez Domingo ${ }^{6}$

José Maria Eiros Bouza

José González ${ }^{8}$

Diego Gracia 2,9

Ricardo Juárez González ${ }^{10}$

Patricia Muñoz $1,3,4$

Roberto Petidier

Torregrossa ${ }^{11}$

José Manuel Ribera

Casado 8,12

Primitivo Ramos Cordero ${ }^{13}$

Eduardo Rodríguez Rovira ${ }^{14}$

María Eva Sáez Torralba ${ }^{15}$

José Antonio Serra

Rexach ${ }^{16,17}$

Javier Tovar Garcia ${ }^{18}$

Carlos Verdejo Bravo ${ }^{19}$

Esteban Palomo ${ }^{2,8}$

\section{The situation of infection in the elderly in Spain: a multidisciplinary opinion document}

${ }^{1}$ Respiratory Diseases CIBER (CIBERES CB06/06/0058), Spain.

${ }^{2}$ Health Sciences Foundation.

${ }^{3}$ Microbiology and Infectious Diseases Department, Hospital General Universitario Gregorio Marañón.

${ }^{4}$ Department of Medicine. Complutense University of Madrid.

${ }^{5}$ Llefià Primary Care Centre. Badalona. Barcelona. National Coordinator of the Urology (Nephrology and Urinary Tract)

Working Group of SEMERGEN.

${ }^{6}$ Vaccine Research Area. FISABI0-Public Health, Valencia.

${ }^{7}$ Microbiology Department. "Río Hortega" Faculty of Medicine and University Hospital. Valladolid.

${ }^{8}$ Universidad Complutense, Madrid.

${ }^{9}$ Medical School. Universidad Complutense, Madrid.

${ }^{10}$ Network of Experts and Professionals in Emergency Medicine. Castilla la Mancha Healthcare System (Sescam). Hospital

Nuestra Señora del Prado Emergency Department.

${ }^{11}$ Geriatrics Department. Getafe University Hospital. Madrid

${ }^{12}$ Royal National Academy of Medicine.

${ }^{12}$ Madrid Agency of Social Care. General Secretary of the Spanish Society of Geriatrics and Gerontology. Madrid.

${ }^{14}$ Spanish Confederation of Elderly Organisations (CEOMA). Madrid.

${ }^{15}$ Buenavista Healthcare Center. Coordinator of INR Training, Family and Community Nursing Specialty. Toledo

${ }^{16}$ Geriatrics Department. Hospital General Universitario Gregorio Marañón. Universidad Complutense. Madrid.

${ }^{17}$ Fragility and Healthy Ageing CIBER. Carlos III Healthcare Institute. Madrid, Spain.

${ }^{18}$ EFE Agency. Madrid.

${ }^{19}$ Geriatrics Department. Hospital Universitario Clinico San Carlos. Madrid. Universidad Complutense, Madrid.

\section{Article history}

Received: 16 June 2020; Revision Requested: 29 June 2020; Revision Received: 12 July 2020; Accepted: 14 July 2020;

Published: 8 September 2020

\section{ABSTRACT}

Infection in the elderly is a huge issue whose treatment usually has partial and specific approaches. It is, moreover, one of the areas where intervention can have the most success in improving the quality of life of older patients. In an attempt to give the widest possible focus to this issue, the Health Sciences Foundation has convened experts from different areas to produce this position paper on Infection in the Elderly, so as to compare the opinions of expert doctors and nurses, pharmacists, journalists, representatives of elderly associations and concluding with the ethical aspects raised by the issue. The format is that of discussion of a series of pre-formulated questions that were discussed by all those present. We begin by discussing the concept of the elderly, the reasons for their predisposition to infection, the most frequent infections and

Correspondence:

Emilio Bouza MD, PhD

Instituto de Investigación Sanitaria Gregorio Marañón.

C/ Dr. Esquerdo, 46

28007 Madrid, Spain

Phone: +34- 91- 5868453 / Fax: +34- 91- 5044906

E-mail:emilio.bouza@gmail.com

Esteban Palomo, PhD

Director. Health Sciences Foundation

C/ Severo Ochoa 2

28760 Tres Cantos. Madrid

Phone +34913530150 their causes, and the workload and economic burden they place on society. We also considered whether we had the data to estimate the proportion of these infections that could be reduced by specific programmes, including vaccination programmes. In this context, the limited presence of this issue in the media, the position of scientific societies and patient associations on the issue and the ethical aspects raised by all this were discussed.

Key-words: Infection in the elderly, elderly, aged, nursing homes, Urinay tract infection, pneumonia, burden of infection, vaccines, ethics.

\section{Situación de la infección en el anciano: un documento multidisciplinar de opinión}

\section{RESUMEN}

La infección en los ancianos es un tema enorme que suele recibir enfoques muy específicos pero parciales. Además, es una de las áreas en las que la intervención podría tener más éxito para mejorar la calidad de vida de los pacientes mayores. En un intento de dar el mayor enfoque posible a este tema, la Fundación de Ciencias de la Salud ha convocado a expertos de diferentes áreas para elaborar este documento de opinión sobre la situación de la infección en los ancianos, tratando de comparar las opiniones de médicos expertos, enfermeras, farmacéuticos, periodistas, representantes de asociaciones de ancianos y terminando con los aspectos éticos que plantea el problema. El 
formato es el de la discusión de una serie de preguntas preformuladas que fueron discutidas entre todos los presentes. Empezamos discutiendo el concepto de "anciano", las razones de la predisposición a la infección, las infecciones más frecuentes y sus causas, y la carga laboral y económica que suponen para la sociedad. También preguntamos si teníamos datos para estimar la proporción de estas infecciones que podrian ser reducidas por programas específicos, incluyendo programas de vacunación. En este contexto, se discutió la baja presencia de este problema en los medios de comunicación, la posición de las asociaciones científicas y de pacientes sobre el problema y los aspectos éticos que todo esto plantea.

Palabras clave: Infección en la vejez, ancianos, asilos, infección del tracto urinario, neumonía, carga de la infección, vacunas, ética.

\section{INTRODUCTION}

The ageing of the population in more developed societies is an incontrovertible fact. In the face of the indisputable success in achieving a longer life for a large proportion of the population, questions arise as to the viability of social protection systems.

By 2030, over 25\% of the population will be classed as elderly and their quality of life will depend, to a large extent, on avoiding preventable diseases such as Infectious Diseases.

It is a well-known fact that the elderly constitutes a risk group for distinct types of infectious diseases, whose diagnosis and treatment are hindered by several factors. Around this fundamental fact, however, we find a lack of answers to simple questions about the size of the problem, its epidemiology, the capacity of the social response to it and the need to plan useful preventive measures to minimise risk and reduce costs.

For this reason, the Health Sciences Foundation, which has Prevention as one of its main objectives, has organised a discussion and opinion meeting on the Infectious Diseases situation in the elderly in Spain, aiming to answer a series of questions accepted by all the participants.

This document attempts to reflect the main issues discussed, the documentation provided and the conclusions reached by the group. The document does not intend to provide any recommendations or therapeutic guidelines, but simply to contribute data to the debate on Infection in the elderly population, particularly in Spain, and to point out some possible solutions to it.

This meeting was held months before the COVID-19 epidemic that has certified many of our concerns.

The final document has been approved by all participants and represents their joint opinion.

\section{MATERIAL AND METHODS}

The questions were chosen by the coordinators and accepted by all the speakers.

The document edited in a first draft was sent to all co- authors for their corrections and amendments. The final document has been reviewed by all the authors.

We will now review the questions posed, the arguments made and the conclusion reached for each one.

What do we mean when we talk about the elderly? How many are there in Spain? How many will there be in the near future?

Presentation:

The WHO publishes reports on ageing and health, or old age and its consequences, on a regular basis, at least since the 60 's. Cited here are a few more. We reproduce a paragraph in full $[1,2]$ "Today, for the first time in history, most people can aspire to live beyond the age of 60 . In low and middle-income countries, this is largely due to the significant reduction in mortality in the early stages of life, especially during childbirth and infancy, and in mortality from infectious diseases. In high-income countries, the sustained increase in life expectancy today is mainly due to the decline in mortality among older people". The report focuses on a redefinition of healthy ageing based on the notion of functional capacity: the combination of the individual's intrinsic capacity, relevant environmental characteristics and the interactions between the individual and these characteristics.

In Spain, according to data from the National Institute of Statistics[3], 18.7\% of the population is currently over 65 . That's about 8.7 million people. If we focus on those over 85 , they currently account for $6 \%$ of the total population (about 2.8 million). Forecasts for 2031 put the number of people over 65 years old at 12 million (26.2\% of the population) and those over 85 at 3.9 million (8.5\% of the population). Thus, between 1960 and 2031, the number of people over 65 will have increased by a factor of 5 (from 2.5 to 12 million), and the percentage will have increased by a factor of 3 (from 8.2 to 26.2 $\%)$, while the number of people over 80 will have increased by a factor of 10 (from 370,000 to 3.9 million) and the percentage will have increased by a factor of 6 (from 1.2 to 8.5 per \%).

Once the figures have been established, it is necessary to clarify that, according to the Dictionary of the Royal Spanish Academy of Language (DRAEL), "old" is "that person of age, commonly one who has turned 70". However, age is a purely theoretical value to distinguish a person as "old" or "elderly". Taking the age of 65 as the threshold for the onset of old age dates back to the late 19th century, when less than 10\% of those born reached that age. Today, more than $90 \%$ of people reach the age of 65 , so this age limit is shifting towards older ages.

Nowadays the concept of "old" is more related to "function" than to age. Thus, the DRAEL defines health as "that state in which the organic being normally exercises all its functions". Therefore, one of the most relevant aspects in considering a person "old" is that they need help to carry out the activities of daily life (bathing, dressing, feeding, moving, etc.). We can find totally independent people in their 80's and others with a high degree of dependency in their 60's. 
Therefore, the "elderly" is an enormously heterogeneous group in aspects such as the prevalence of chronic diseases (ischaemic heart disease, hypertension, diabetes, COPD, etc), the need for consumption of drugs and the existence or nonexistence of physical, mental (dementia, depression) and social (Ioneliness, isolation, poverty) problems.

\section{Conclusion:}

- The definition of elderly is artificial and refers to any person over a certain age (which can be set at 65, 70 or older) who has serious limitations in the exercise of their physical, mental or social functions.

- In our society, currently, almost $20 \%$ of the population would meet a definition of elderly based exclusively on the criterion of age, but it is estimated that, with this criterion, the percentage in Spain will be greater than $25 \%$ by the year 2031 .

\section{What are the reasons for the elderly person's predis- position to infection?}

\section{Presentation:}

The changes that take place throughout the ageing process favour the existence of infections. The simplest explanation is that with age the numerator of the aggression/defence equation increases (greater arrival of microorganisms that are also more virulent) and the denominator decreases (less defence capacity on the part of the organism). We can therefore divide the causes of the elderly person's predisposition to infection into those that depend on the microorganisms and those that depend on the host's defence mechanisms.

There is no evidence that the microbiota of the elderly is quantitatively different from that of younger populations, nor necessarily more aggressive. However, it is an incontestable fact that previous infections, antimicrobial treatments, the greater ease of microorganism acquisition and living in proximity to other elderly people, can predispose the elderly to colonization and subsequent infection by multi-resistant microorganisms, with the presence of "superinfections", with a worse response to antimicrobials and increased resistance to them.

In terms of host defence mechanisms, there are many factors that make the elderly more labile. Mechanical barriers, for example, are the first element of defence, but they deteriorate progressively throughout the ageing process, facilitating the entry of microorganisms. The skin and mucous membranes experience physiological losses and often also those resulting from local or systemic diseases. The most important changes are: thinning, with loss of epithelial and mucosal cells, worse hydration and vascularization, loss of elasticity, decrease in mucous gland secretions of antimicrobial peptides, worse healing, loss of cellular macrophages in the skin (Langerhans cells) and immobility with increased local pressure in certain areas.

In the respiratory system, there is a decrease in the number of cilia and a slowing down of their activity, a reduction of alveolar macrophages, a decrease of the cough reflex and greater difficulty in eliminating secretions. In the digestive tract it is common to find diverticuli in the mucosa that act as microorganism reservoirs. Also, losses in secretory function with a tendency to gastric achlorhydria, but, above all, motor function which at oesophageal level, can favour aspiration phenomena. In the urogenital system there are usually alterations arising from pregnancy, childbirth, previous surgeries and local manipulations that make the free flow of urine difficult. In this vein, it is worth adding the frequency of subjecting the elderly to diagnostic or therapeutic examinations that may favour infections.

In addition to the deterioration of mechanical barriers, there are losses in non-specific defence mechanisms. These include limitation to increase blood flow and vascular permeability at the infection entry points. The ability to mobilise polymorphonuclear leukocytes rapidly and the agility of phagocyte function is also impaired. Chemotactic capacity decreases from the age of 70, as does the capacity for the intracellular destruction of microorganisms. Ageing is associated with a chronic, progressive, nonspecific, low-level pro-inflammatory state, for which the English literature has coined the term "inflammageing", which favours an environment conducive to infection and further limits the possibilities of an effective response to it.

The deterioration of adaptive immunity ("immunosenescence") associated with the ageing process has been known for years and affects both innate and acquired immunity [4-6]. Immunosenescence includes qualitative losses in T-lymphocyte subpopulations with decreased activity of CD-4 helpers, cytotoxic CD-8s and a limitation in generating T-cell growth factor. Ageing determines a tendency to invert the CD4/CD8 T-cell ratio. The number of dendritic cells decreases with age and the response of NK cells to stimulating cytokines is limited. It also increases the activity of CD-8 suppressors. B-lymphocytes are limited in their ability to produce antibodies and to respond to external antigens. Furthermore, there is an increase in the production of autoantibodies and circulating immune complexes.

A third group of factors that add to the microorganisms and the individual are environmental and social factors, such as hygiene neglect, poverty, isolation and a sedentary lifestyle. The fact of living in nursing homes and the increase in hospitalisations favours an insufficiently quantified environmental exposure [7].

\section{Conclusion:}

There are multiple factors that explain the higher incidence of infections in the elderly. The clearest are those that have to do with alterations of the defensive barrier mechanisms. Immunosenescence is a complex concept involving various alterations in the immunity of the elderly.

What are the main clinical syndromes of infection in the elderly?

Presentation:

The frequency and even the aetiology of infections af- 
fecting the elderly vary depending on the clinical environment (home, nursing home, hospital) and the functional status of the patient. In older, independent and healthy people, respiratory conditions caused by viruses or bacteria prevalent in the community, Urinary Tract Infections (UTIs), whether catheter-related or not, and intra-abdominal infections (cholecystitis, diverticulitis) are common. In contrast, in institutionalised elderly people, UTIs related to the bladder catheter, aspiration pneumonia, skin and soft tissue infections and those of the Gastro-Intestinal Tract (GIT) predominate. In hospitalised elderly people we have to consider nosocomial pneumonia, intravascular catheter associated infections and $C$. difficile infections as the most prevalent [8-14].

There is limited data analysing the comparative overall frequency of the different syndromes. In elderly people living in nursing homes, UTIs (at least 30-40\% of healthcare-associated infections), respiratory infections, skin and soft tissue infections and those of the GIT predominate [15]. In a recent Spanish multicentre descriptive study, conducted in 49 Emergency Departments, 11,399 patients were included, of whom $4,255(37.3 \%)$ were at least 65 years old. Compared to younger adults, older patients (mean 78.8 years) had respiratory, urinary and intra-abdominal infections more often, while there was no difference in the frequency of other syndromes [16]. These data are confirmed in Chinese studies that analyse elderly patients attending Emergency Departments and also show a significantly higher incidence of respiratory and urinary infections $[17,18]$.

In the case of UTIs, the relative prevalence is influenced by the gender of the patient. Thus, for long-term care facility (LTCF) residents and in hospitalised elderly people, UTI is the number one cause of infection and is the second most common in older women living in the community [19]. The incidence in men ranges from 0.05/person year $(1 / 20)$ in men aged 65-74 and reaches $0.08(1 / 12)$ in men over 85. In women, the incidence of UTI increases with menopause (0.07 per person/ year: $1 / 14)$, increasing to 0.13 per person-year $(1 / 7.5)$ after age 85 [20]. In indwelling catheter-wearing patients, the incidence of UTIs is 3.2 cases per 1,000 catheter days, compared to only 0.57 per 1,000 days for all residents $(\mathrm{x} 18)$. Urinary tract bacteraemia was 3-39 times more common in patients with permanent urinary catheterization [20] and UTI is also the most frequent cause of community-acquired bacteraemia in the elderly (40-57\%).

With respect to respiratory infections, the annual incidence of Community Acquired Pneumonia (CAP) ranges from 8-18.2 episodes per 1,000 people over 65 years of age and represents $30-40 \%$ of hospitalisations in this age group [21]. In Japan, $96 \%$ of deaths from pneumonia occur in patients over 65 years of age. The risk of CAP is 4 times higher in those over 65 compared to those under 45 and 10.8 times higher in those over 85 compared to adults aged 50-64. Viral infections are also common in this age range, as we will see later.

\section{Conclusion:}

The most prevalent infections in the elderly de- pend on their situation. In independent elderly people, the most common infections are respiratory conditions caused by viruses or bacteria prevalent in the community, urinary tract infections and intra-abdominal infections. In contrast, in institutionalised elderly people, bladder catheter-related UTIs, aspiration pneumonias, skin and soft tissue infections, and infections of the gastrointestinal tract predominate.

Which microorganisms are most common? How does the problem of multi-resistance impact on the elderly?

\section{Presentation:}

It is important to remember that infections in the elderly may be caused by a greater variety of microorganisms than in the younger population, so it is essential to obtain samples for culture before administering empirical antimicrobial treatment [8]. Thus, for example, while the vast majority of UTIs in young patients are caused by $E$. coli, in the elderly their relative importance is less. In the case of pneumonia, there is a higher incidence of Gram-negative bacilli (GNB) and as far as meningitis is concerned, they are rarely of viral aetiology, while we must consider GNB and Listeria monocytogenes.

In a Spanish study, including 333 elderly patients (mean age 81.6 years), with UTIs, the most frequently isolated microorganisms were E. coli, (67\%), Enterococcus faecalis (15\%), Klebsiella pneumoniae (10\%) and Pseudomonas aeruginosa (9\%). In up to $8 \%$ of cases, more than one microorganism was isolated in the urine. The frequency of bacteraemia was higher with E. coli and lower with E. faecalis and P. aeruginosa and bacteraemia was not associated with a worse prognosis [22]. The frequency of multi-resistance increases with age and comorbidity. In this Spanish study, the proportion of Extended-Spectrum Beta-Lactamase (ESBL) producing E. coli and K. pneumoniae isolates was $20.1 \%$ and $36.3 \%$, respectively. In the previously mentioned study of patients attending the Emergency Department, the elderly accumulated more risk factors for multi-resistance $(p<0.001)$ and suffered from septic syndrome more frequently $(p<0.001)$ [16].

There are few studies that analyse the overall aetiology of respiratory infections in older patients, and most work focuses on describing specific populations or groups of pathogens. The aetiological affiliation rate of respiratory infections in the elderly is very low $(<30 \%)$, and this is due, among other things, to the difficulty many patients have in producing sputum and to the high frequency of empirical treatment [21]. If we analyse the aetiology of CAP, the most frequent pathogen is S. pneumoniae (20-80\%), followed by H. influenzae (3-39\%), respiratory viruses (3-30\%), Legionella spp.(1-17\%) and GNB $(3-14 \%)$. It is also necessary to remember the importance of viral pathogens in this population, since the prescription rate of unnecessary antimicrobials is very high in them (46\% of the elderly with viral symptoms) [23]. In a study conducted in China, in 6 sentinel hospitals, it was observed that $31.64 \%$ of elderly patients with respiratory infection had a viral aetiology (41.8\% among extra-hospital infections and 25.7\% among 
nosocomial infections) [24]. The most common cause was influenza (14\% of all patients studied). RSV is also a significant pathogen in this population $[25,26]$.

The most important cause of GIT infection in the elderly is Clostridioides difficile. C. difficile (C-diff) infection is currently the most prevalent nosocomial infection, affecting in more than 70\% of the episodes patients over 65 years of age [27]. Moreover, it is in this population that C-diff causes the highest morbidity and mortality, with an increase in C-diff-related mortality from 5.7 to 23.7 deaths per million population per year from 1999 to 2004 [28] in patients with an average age of 84 years having been described in the USA. It is interesting to note the safety of using the same therapeutic options in elderly patients, including faecal microbiota transplantation $[29,30]$.

\section{Conclusion:}

The microorganisms causing infection in the elderly are qualitatively the same as in the population of other age groups, although there are quantitative variations. Depending on the type of infection there is a greater predominance of infection by Gram-negative bacilli. Underlying diseases, and the aforementioned treatments increase the risk of infection by multi-resistant bacteria.

\section{Where do they get these infections? What proportion are acquired in nursing homes? At home? In hospital? - \\ Presentation:}

In addition to the hospital and home environment, the elderly can acquire infections elsewhere, and in particular in other care units. This is the reason why, almost 20 years ago (2002), the term "Health care-associated infection" began to be used, which is not only limited to hospitalized patients, but also extends the concept to patients in contact with the health system (home care of patients with high comorbidity and complexity; Day Care Centres; Major Outpatient Surgery Units; Outpatient Dialysis Centres; Community Health Centres for chronic or convalescent patients).

To a great extent, it is in Nursing Homes where patients with more comorbidities, polypharmacy consumption, a high degree of dependency and a high prevalence of invasive devices (bladder catheter, nasogastric tube, percutaneous gastrostomy) will be treated. In addition, the environment can facilitate the transmission of microorganisms between residents and healthcare personnel, as well as between residents. For all these reasons and the excessive or inappropriate use of broad-spectrum antibiotics, either empirically or prophylactically, Multi-Drug-Resistant (MDR) infections can be generated. Implementation of effective preventive measures in this population is very difficult to organise.

In the United States of America, it is estimated that approximately 1.5 million people live in nursing homes and suffer between 1.6 and 3 million episodes of infection annually [31]. The prevalence of infections in these residences is estimated at $10 \%$ of the residents [32] and the incidence of new infections is estimated at between 4 and 5 episodes per 1,000 days of stay in the residence $[33,34]$. The figures rise to 11 for those with some kind of prosthetic material [35].

We have several European HALT studies (Healthcare-associated infections and antimicrobial use in long term care facilities), with participation from 24 countries, including Spain, with a prevalence of infection of $4.7 \%$ and $5 \%$ at two different times [36-38].

A French multi-centre study, conducted in 578 nursing homes with 445,000 beds, shows an infection prevalence of $11.23 \%$ [39].

The first data on infection in nursing homes in Spain come from the EPINGER study, conducted in community health centres in Catalonia, which reported a prevalence of 6.5\%, although it should be pointed out that in Catalonia the concept of the community health centre would include medium-long term patients, while in the rest of the Spanish autonomous communities this concept would be limited to nursing homes [40]. In another study, conducted by San Sebastian's Fundación Matía, an infection prevalence between $6.44 \%$ and $4.80 \%$ was reported [41].

Data derived from the VINCat study in Catalonia show a prevalence of healthcare-associated infection in long-term care centres of $10.2 \%$, with a great diversity, depending on the type of care unit (subacute $22.3 \%$, palliative $18.7 \%$, convalescent $11.7 \%$, long stay $8.1 \%$ )[42].

Home is the most recommendable place for the healthy elderly to live, and even for the elderly patient, with healthcare falling to Primary Care professionals, although sometimes with the collaboration of some hospital resources.

The Ministry of Health, Social Services and Equality has for the first time published the results of the Primary Care Clinical Database (BDCAP), a tool that allows for a more precise and systematized knowledge of the main health problems in Spain dealt with by the doctors on the healthcare frontline. Thanks to this register, a detailed picture of the health problems of the Spanish population is available from Primary Care [43]. In this database, infections appear among those over 64 years old with an elevated frequency of 634.1 cases a year per 1,000 people (569.9\% men and 682.7\% women). The most frequent correspond to the respiratory system (317 cases/1000 persons/year), followed by urinary tract infections with (84.4 cases/1000 persons/year) and clear female predominance.

Finally, nosocomial infections are those that occur in hospitalized patients and are present more than 48 hours after admission. They are acquired by transmission from the environment, from other patients or from healthcare personnel. They are considered to be the most preventable cause of serious adverse events in hospitalised patients [44]. In general, these infections are related to invasive diagnostic or therapeutic procedures (urethral catheterization, surgical procedure, vascular catheter, invasive mechanical ventilation), all of which have in common the disruption of the host's own defences by a device or an incision, allowing the invasion of 
microorganisms that are part of the patient's usual microbiota (endogenous microbiota), or selected by the selective antibiotic pressure (secondary endogenous microbiota), or by one found in the hospital environment (exogenous microbiota).

To understand the main epidemiological data on hospital infections, the EPINE study (Estudio de Prevalencia de las Infecciones Nosocomiales en España (Study on the Prevalence of Nosocomial Infections in Spain)) was developed. This is a multi-centre system for monitoring nosocomial infections, based on the production of an annual prevalence study, which has been conducted since 1990 in a large group of hospitals in Spain and was promoted by the Spanish Society of Preventive Medicine, Public Health and Hygiene. Its methodology guarantees a homogeneous and systematic collection of information, which allows us to understand the prevalence of Healthcare-Associated Infections (HAls) at a national level, by Autonomous Regions and hospitals. Since 2012, every 5 years the EPINE study has been produced jointly with the European study (in 2012 and 2017) under the coordination of the ECDC [45].

Based on the latest data published, in November 2017 (313 hospitals and 61,673 patients), a prevalence of nosocomial infection in patients over 65 years of age of 6.07\% (infections acquired during the current admission), 7.45\% (infection acquired during the current or previous admission) and $8.76 \%$ (the total, including the centre's own or imported) has been reported. It should also be noted that this register shows that in $22 \%$ of patients over 65 years of age admitted for an infection, the infection had been acquired in the community (patient's home).

\section{Conclusion:}

The home, nursing homes and community health centres, healthcare centres other than hospitals and the hospital itself are often the places where the elderly acquire infections. The studies reviewed allow us to estimate a prevalence of infection of between 4 and $10 \%$ in nursing homes in Spain, depending on their complexity, and between 6 and $9 \%$ in hospitalised elderly people. In Primary Care and in the Residential environment, there is no homogeneous epidemiological record of this problem.

\footnotetext{
What proportion of severe infections in the elderly require hospitalisation? By whom are they treated?

Presentation:

In the United States of America, patients over 65 years of age account for almost 40\% of total adult admissions and the cost of these hospitalisations represents nearly $50 \%$ of the total cost for hospitalisation, although those over 65 years of age account for less than 20\% of the total adult population $[46,47]$. Those over 65 years of age are admitted to hospital three times more often than those between 45 and 65 years of age, and those aged 85 or over account for $9.2 \%$ of all hospital discharges, although they represent only $1.8 \%$ of the population as a whole.
}

Infectious diseases are the second cause of such admissions (16.2\%), only surpassed by cardiovascular diseases (28.6\%). Pneumonia and sepsis are the most common infections causing admission in this population [48]. The elderly population also has longer hospital stays (5.5 days for those over 265 ) than those between 45 and 64 (5.0 days) and those between 15 and 45 (3.7 days) [49].

The elderly are treated by virtually every unit in a hospital but it is worth mentioning that those over 65 years of age represent 40\% of those admitted to Intensive Care Units [50]. The other group of interest is that of specialised geriatric units, not available in all hospitals, which have been shown to improve the functional status of patients and reduce the number of discharges to long-term care homes [51].

In a study by Saliba et al., conducted in Israel [52], out of a total of 81,077 hospital admissions in the elderly between 2001 and 2010, the proportion of admissions due to infectious diseases rose from 16.9\% in 2001 to $19.3 \%$ in 2010. Globally, the most frequent infections causing admission were: those of the Lower Respiratory Tract (LRT) (41.0\%), followed by the UTIs (21.4\%), Upper Respiratory Tract (10.2\%) and hepatobiliary $(9.8 \%)$.

In Spain we do not have precise answers to the questions asked. The proportion of serious infections in the elderly requiring hospitalisation depends on several factors: type of infection, severity of infection and other factors such as the degree of frailty of the elderly, their place of residence and their ability to receive care at home. The environment and the resources available also influence the hospitalisation decision. However, in our environment, most serious infections in the elderly will require hospitalisation for at least a few hours.

In Spain, serious infections in the elderly can be treated by different professionals depending on the type and severity of the infection, and the environment in which it occurs. A high percentage are treated by "generalists" hospital specialists, or geriatricians. Where infectious disease specialists are available they are of course involved in their management, either in beds in their own departments or as consultants. They can also be treated by specialists of the affected organ such as orthopaedic surgeons in the case of infections of prosthetic material, or vascular surgeons in the case of infections of vascular ulcers. And if, in the end, hospital admission is not decided, the patient is cared for by the primary care team.

As an example, we have collated the urinary tract infections treated at the Hospital General Universitario Gregorio Marañón between 2015 and 2018. When UTI is the main diagnosis that motivates admission (about 700 cases a year) about $90 \%$ of cases are cared in the Medical Departments. When it comes to secondary diagnosis (about 2,000 cases per year), the Internal Medicine and Geriatrics Departments take care of about $75 \%$ of the cases.

Preventive programmes, such as flu vaccination programmes, reduce the need for hospitalisation for respiratory infections by nearly 30\%, both inside and outside Spain [53-55]. 


\section{Conclusion:}

- It has not been possible for us to answer precisely the question about hospitalisation figures for infection in the elderly in Spain. Data from outside Spain allow us to estimate that infection is the second cause of admission in patients over 65 years old and that pneumonia and other causes of bacterial sepsis are the main reasons, particularly sepsis of urinary origin.

- Only a minority of the elderly admitted for infection are treated in specific geriatric units and most are admitted to general medical departments.

What is the workload represented by elderly patients in Hospital Emergency Departments?

\section{Presentation:}

The number of visits to Hospital Emergency Departments (ED) has been increasing progressively for decades. This increase is greater in the elderly, whose population accounts for $15-25 \%$ of all visits to the hospital [56]. The incidence and impact of infection in the ED is estimated quite reliably. In Spain it is $14.3 \%, 21 \%$ in the USA and around $30-40 \%$ in countries such as Nicaragua and Mexico [57].

The elderly are characterised by a higher probability of atypical presentation of diseases, of suffering from multiple diseases and of consuming many drugs. With regard to emergency care, this implies a more complex clinical evaluation, which translates into a greater request for additional tests and consultations with other specialists, longer stays in the ED (extended periods under observation and in SSUs), as well as a greater probability of admission, discharge with undetected or untreated problems and return visits to the ED [58]. All this entails a high risk of adverse episodes [58] and a significant impact on healthcare pressure, resulting in a negative effect on ED saturation $[59,60]$.

Likewise, the prevalence of the frail elderly in the community varies according to the diagnostic criteria. In a study conducted on elderly people admitted to the observation room of an ED in a Spanish tertiary hospital, it was verified that only one of them did not have any fragility criteria and on admission almost half of them suffered significant dependence [61]. The detection of the high-risk or fragile patient is fundamental for these Departments, for decision-making and in particular for discharge directly from the Emergency Department.

We could highlight that in the recent work of the INFUR-SEMES group, in a study conducted in 49 Spanish EDs, $31.7 \%$ of infections occurred in patients over 70 years old. Of these, 36\% were urinary and $51.2 \%$ were lower respiratory. In conclusion, when compared with a similar study, conducted twelve years earlier, an increase in the prevalence of infections is observed, with an older patient profile, comorbidity, risk factors for MDR microorganisms and septic syndrome [62]. The latter almost always presents itself as an acute confusional syndrome, which implies a complex differential diagnosis.
Moreover, in our opinion, in these departments, emergency assessment should not be focused only on the isolated episode for which the patient consults, but the particulars of the elderly person, their functional, mental and social situation should be taken into account. This is a huge workload for the ED.

Finally, we should bear in mind that the training of ED physicians on these issues is limited [63] as a direct consequence of the self-training of current professionals, which is not always complete, and the lack of a regulated medical specialty in the ED.

\section{Conclusion:}

In Spain, between 15 and 25\% of Emergency Department visits occur in the elderly. Elderly people come in $14.5 \%$ of the time for infections and one third of the infections seen in the Emergency Departments occur in the elderly. The population over 65 years of age who attend the Emergency Department often have multiple pathologies and clinical manifestations of infection that may be atypical.

How much of infection in the elderly is resolved in primary care? How much of the vaccination is done at the primary care clinic?

\section{Presentation:}

In the Spanish National Health Service, emergency activity accounts for a total of 47.2 million consultations per year, of which 26.5 million are attended to in primary care (PC) (outpatient or home), with an average attendance of 0.6 people/ year [64]

One-third of emergency consultations in PC are related to infections [65]. In the older patient, infections are more frequent and serious, associated with greater morbidity and mortality [65-67].

Among the elderly, the rate of infection reaches 634.1 cases per thousand people per year. The most frequent correspond to the respiratory system (317 cases per thousand), particularly those of the upper respiratory tract, followed by acute bronchitis and bronchiolitis and pneumonia $[65,67-$ 69]. In second place are UTIs, mainly affecting women (114.8 cases per thousand compared to 44.2 per thousand for men) [67]. These are followed by skin and soft tissue infections [69]. Most of these cases are dealt with in Primary Care and only those more serious situations and of uncertain diagnosis are referred.

In 75\%-80\% of cases, CAP is diagnosed in PC $[65,70]$ and Streptococcus pneumoniae is the cause of two-thirds of these cases. Invasive forms of pneumococcal disease (IPD) are less common, occur in patients with certain risk factors and have high mortality rates [70].

The vast majority of vaccination programmes in Spain are carried out in primary care, but the vaccination schedule for older people is neither complete nor promoted as it should be. 


\section{Conclusion:}

The infection rate in the elderly exceeds 500 episodes per 1,000 sick people per year. Primary care handles the vast majority of these episodes and refers only the most serious cases.

Primary care is responsible for the vaccination programme for elderly people who attend to request it. The vaccination schedule for older people is neither comprehensive nor proactively promoted.

What does infection in the elderly entail in terms of days of hospitalisation, financial expenditure and death?

\section{Presentation:}

To approximate data/figures for variables such as "days of hospitalisation, economic expenditure and death" in a field as broad as "infection in the elderly" is enormously complicated. It must be taken into account that the infectious pathology is very varied and that it can affect people with different locations (community, community health centre or the hospital itself) and conditions. For example, with reference to nursing homes, Lim et al. estimate 4 episodes of infection for every 1,000 cumulative days spent in the home in a small group in Australia [71], while much more extensive North American data report $12 \%$ of nursing home residents having an infection at the time of the study [32]. This leads to estimates of between 1.64 and 3.83 million episodes of infection per year [31] with annual costs of no less than US\$ 1 billion, prior to 2000 .

In a study conducted in Brazil, the cost of an infection in the elderly requiring admission is estimated at 28,714 Brazilian reals $(€ 6,305)$. Patients are admitted for a median of 24 days compared to a median of 9 days for elderly people admitted for non-infectious causes [72]. Of that cost, only 5\% is attributable to the purchase of antibiotics.

In a multinational clinical trial on skin and soft tissue infections comparing linezolid with vancomycin, involving 1,200 individuals, $22.7 \%$ of the patients were over 65 years of age. The length of hospital stay in elderly patients was 6.8 days in patients receiving linezolid versus 10.3 days in those receiving vancomycin. The average cost of hospitalisation was $\$ 4,510$ in 2002 compared to $\$ 6,478$ for those treated with vancomycin.

There is a greater volume of data for community-acquired pneumonia (CAP) [73-76]. The cost of CAP varies greatly depending on where the treatment takes place. A Spanish study [77] found a cost of only $€ 196$ in the case of an outpatient, compared to $€ 1,153$ for pneumonia requiring hospitalisation. The costs were higher for subjects $\geq 65$ years.

Mortality increases significantly in the older patient (25\%) with respect to the general population (10\%). It is worth noting a publication in Spain with a sample of 2,049 subjects, where mortality due to pneumonia is more clearly related to the age group than to the aetiological agent [78].

\section{Conclusion:}

We have not found precise data calculating overall days of hospitalisation, mortality rates and the cost of infection in the elderly. Data are only obtained for specific types of infections and in certain situations (nursing homes), but there is no doubt that the figures are very high.

To what extent do you think that infection in the elderly is preventable? What proportion could be avoided with proper vaccination?

\section{Presentation:}

In an article published by Umscheid et al. [79], not specifically addressing to the elderly field, it is estimated that 65\%$70 \%$ of cases of catheter-related bacteraemia or catheter-associated urinary tract infection and 55\% of pneumonias from mechanical ventilation or skin and soft tissue infections could be prevented in the hospital environment using the methodology currently available.

An infection control programme for older patients includes methods for surveillance and recording of infections, recording and management of multi-resistant microorganisms, outbreak contingency plans, isolation policy and standard precautions, hand hygiene programmes, ongoing education of employees, resident health plans, audits and plans for reporting incidents to health authorities [80]. This set of resources is not available to most of the world's elderly.

A group of experts, gathered in a Delphi study on infection prevention measures in patients admitted to institutions for the elderly, agreed on 302 recommendations [81] but unfortunately the level of evidence on the effectiveness of each of them is very limited.

Data on the reduction of different infections by different measures are extremely scattered and limited. Some examples are the reduction by 53\% of periprosthetic infections with antibiotic prophylaxis [82], a 60\% reduction in episodes of influenza with the physical separation of the young and the elderly, [83] or a $48 \%$ reduction in episodes of pneumococcal pneumonia with the 23 -valent vaccine [84].

Makris et al. [85] conducted a study to test the effect of an infection control programme in 8 institutions for the elderly in the United States of America. They divided the centres into test centres (4) and control centres (4) and studied the incidence of infections in both groups before and after the programme was introduced. In the year prior to the intervention, test sites experienced 743 infections (incidence density rate, 6.33) and control sites 614 infections (incidence density rate, 3.39). In the intervention year, the test centres reported 621 infections, a decrease of 122 infections (incidence density rate, 4.15), while in the control centres, the number of infections increased slightly to 626 (incidence density rate, 3.15). The greatest reduction in infections at the testing centres was in upper respiratory tract infections $(P=0.06)$. The intervention programme consisted mainly of implementing environmental cleanliness, hand washing programmes and educational talks.

Therefore, and speculatively, we dare to estimate that a 
high quality infection control programme in nursing homes could reduce infection rates by up to $50 \%$. But even if we estimate much lower figures, the impact on morbidity, mortality and the economy of such programmes would be enormous and would certainly outweigh their implementation costs.

With reference to the second part of the question, the possibility of reducing the problem with vaccines, the data are again scattered and studied for different vaccines individually. In addition, information on the elderly must often be inferred from data on the general population. We refer readers to a recent review on the subject[86].

Below is some data on the impact of vaccines of particular interest to the older population. Gross et al. [87] in a meta-analysis of 20 cohort studies estimate the effectiveness of influenza vaccination at 56\% in preventing respiratory infections, 53\% in preventing pneumonia, 50\% in preventing hospitalisations and $68 \%$ in preventing deaths.

In the case of Zoster, the vaccine's efficacy is estimated at more than 90\% with minimal adverse effects [88]

Different pneumococcal vaccines have different impacts on the incidence of Invasive pneumococcal disease (IPD) infection. A systematic review shows reductions in IPD incidence ranging from $61 \%$ as a combined effect of the use of PCV7, PCV10 and PCV13 in those over 65 in Canada [89] to a 21\% reduction as an effect of the use of PCV7 and PCV13 in Israel [90].

With these data it is possible to imagine the added protection that adequate vaccine coverage would provide. An estimated 50,000 Americans die each year from vaccine-preventable diseases, and 99\% of those who die are adults [86].

Increased provision of medical care in large care homes (e.g. those with more than 200-250 beds) could reduce the referral of many elderly residents to hospital emergency services. This provision of medical care would not necessarily be very complex and would cover both simple diagnostic material and the possibility of establishing and carrying out pharmacological therapeutic courses at the centre itself, the prescription of which in most cases still requires medical staff from outside the centre. It would be a way to reduce costs, lessen the burden on the elderly and reduce the overload on hospital emergency departments.

\section{Conclusion:}

It is impossible to give a precise answer to the questions asked, but it seems reasonable to assume that with appropriate prevention programmes, acquired infections in institutionalised elderly people could be reduced by up to $50 \%$. Strict adherence to a vaccination programme for the elderly would have an enormous impact on reducing suffering, death and economic waste.

What data exist on the effectiveness of educational measures on the incidence of infection in the elderly?

Presentation:
Clearly no one disputes the usefulness of ongoing education in many aspects of life and particularly in the reduction of nosocomial infections. That said, the literature review on the impact of educational programmes on nosocomial infection is irregular, fragmented and often difficult to assess. Published studies generally include education as part of intervention programmes in which other measures are included, making it difficult to assess the role of education in isolation. It is also common to talk about the success or failure of an educational programme without detailing what the programme is, what content it has, how it has been implemented and how many people have accessed it.

To complicate matters, in the case of the elderly, we have at least three different areas: home, nursing homes and institutions for the elderly and hospitals. In the first, the educational scope is very general and imprecise and is based on the public health and vaccination campaigns that are usually received not only by the elderly population but by the population in general. In the hospital field, we must assume that the literature produced on the impact of educational measures in the different syndromic entities generally includes the elderly population, but does not specifically differentiate it. Most of the limited existing information, which we can consider specific to older people, is that generated in nursing homes and institutions that implement these programmes.

A study conducted in the USA on 2,514 randomly selected nursing homes [91] asked the homes for information on 34 points related to infection control programmes. Most of those responsible for control programmes, when they responded, claimed to have not only that responsibility but others as well (54\%) and also to have no specific training in infection prevention (61\%). There was great variability in practices carried out in each residence and 36\% acknowledged having received an official citation for deficiencies in such control. Those residences cited for deficiencies had a statistically lower proportion of staff trained in infection control. This is therefore an area with clear opportunities for improvement.

In a systematic review on non-pharmacological infection prevention in long-term care facilities, only 24 papers were selected, the majority of which were randomised studies (67\%) and the most common reason was prevention of pneumonia (66\%). 54\% showed favourable results for the interventions, but the studies had many potential biases [92-99].

From these studies the 5 main quality markers in infection control in a nursing home were deduced, namely: percentage of long-term patients with pressure ulcers, urinary tract infection, bladder catheter, and vaccinated against influenza and pneumococcal infection.

Conclusion: Without casting doubt on the effectiveness of educational measures in the control of nosocomial infection in general, existing data on the elderly population is very limited, fragmented and generally concentrated in the world of nursing homes. 
What are the great scientific societies doing and what can and should they do to reduce these problems?

\section{Presentation:}

Scientific societies are professional associations that bring together generally specific groups (doctors, nurses, technicians, etc.) that essentially seek to defend the professional interests of their members. Until now, it has not been common for groups of patients affected by different diseases under the thematic umbrella of each society to participate in them. In Spain their impact and political credit is variable.

Among the most important objectives of most of these societies are such issues as training programmes for professionals, aspects related to the health education of the population in their particular field of competence, research grants, the preparation - sometimes in collaboration with societies of another related specialty - of specific diagnostic and therapeutic protocols, publications and congresses focussed on these topics, and a wide range of other activities, including health policy recommendations to the corresponding administrations that have a direct bearing on the issues discussed here.

Membership of societies is also not uniform, and often it is the more "senior" components of the profession that are most highly represented in them.

Their role, in our opinion, is to continue to improve the teaching, care and research produced in the societies' chosen fields in favour of patients, exercising ever greater mediation between the demands of patients and healthcare administration [100]. All societies must go far beyond issuing guidelines and therapeutic recommendations [81, 101-109].

In our view, scientific societies dealing with diseases of the elderly should promote, in the field of infectious diseases, among others, the following topics:

1.- Encourage a proportionate share of its members to subspecialise in infectious diseases.

2.- Coordinate and direct multidisciplinary teams specifically dedicated to the infection in the elderly and its prevention.

3.- Participate more actively in specific programmes to reduce infections in the elderly, both at the nursing home level and at home and in hospital.

4.- Implement vaccination campaigns in the elderly, taking particular advantage of admission to long-stay centres or hospital as opportunities to vaccinate.

5.- To design and disseminate educational projects on infection prevention practices for the elderly in their different environments.

6.- Put pressure on health authorities to carry out a large national programme to reduce infection in older people.

7.- To include in the training programme of residents in Geriatrics, a rotation in Infectious Diseases and Microbiology as an essential part of the curriculum.

8.- Create scientific and professional alliances with socie- ties specifically dedicated to infection. By way of an example, in Spain, this occurs among specialists in Microbiology and Infectious Diseases and Intensive Care specialists.

9.- Specifically promote research aimed at preventing infection in elderly patients.

10.- Introduce much more active involvement of patient associations in their management structures.

What we say about societies primarily dedicated to the elderly, can be similarly assumed and applied to societies primarily dedicated to Infectious Diseases and Microbiology.

\section{Conclusion:}

The role of the scientific societies dedicated to Geriatrics and Infectious Diseases is to promote alliances in the common field of infection, in aspects of care, teaching and research. They need to look less to the interests of their members and be more proactive in promoting the interests of the patients they serve and incorporate patient associations more into their structures.

What capacity do scientists have to influence politicians? Is Parliament sensitive to these problems?

\section{Presentation:}

Capacity, understood as the possibility or potential for influence, is qualified by two variables. Firstly, for offering free and truthful scientific information at the service of the community. And secondly, for facilitating the adoption of the best possible political decisions with consistency and realism.

The rapprochement between professionals in the scientific and political fields must be adjusted to the interest of citizens, who can act as the third pillar in a transparent relationship model and as guarantor of equity befitting a democratic system of government [110]. While scientific experts advise and inform, it is the responsibility of politicians to make decisions and promote efficient measures to the benefit of the population. A complementary characteristic inherent to the scientific task is to exercise a dissemination action of the activity itself, in understandable terms and through accessible and reliable systems [111]. The configuration of platforms within scientific societies and the growing number of independent agencies advising political power represent a reality that aims to bring the contributions of science closer to the systems of governance [112].

In our country, the main function of the Congress of Deputies is legislative, which entails the approval of laws. The Constitution recognises the legislative initiative of the Government, the Congress of Deputies, the Senate, the Assemblies of the Autonomous Communities and the People's Legislative Initiative on the proposal of no less than 500,000 citizens, subject to the provisions of an Organic Law.

These Bills are known in Spain as Law Projects when presented by the Government and Propositions in other cases. They are always submitted to the Congress of Deputies, except for the Propositions of the Senate which have to be considered 
in the Senate, which will later submit them to Congress [113].

Non-legislative Bills, Motions and Proposals for Resolutions are acts of a similar nature that seek the adoption of a non-legislative resolution by Congress, by which Congress expresses its position on a given subject or issue, or addresses the Government urging it to act in a particular direction.

The Health and Social Services Commission of the Congress in the XII Legislature offers access on its website to the 226 initiatives processed since its constitution in September 2016 until its dissolution in March 2019, representing an average of 75 per year[114]. Of these, those referring to the field of infectious pathology as a whole do not exceed $3 \%$. Of particular relevance in the field of infectious pathology have been those relating to the national plan for the elimination of hepatitis $\mathrm{C}$ and antibiotic resistance.

Governance designates the effectiveness, quality and good orientation of State intervention, which provides the State with a good part of its legitimacy in what is sometimes defined as a "new way of governing". Above all, it is used in economic, social and institutional operational terms [115]. An inherent aspect of the exercise of policy is the performance of "Authority", which is equally composed of Legitimacy (right to exercise), Personal Prestige (moral strength, leadership, honesty, knowledge, efficiency) and Power (ability to administer and lead). It is precisely in the "Personal Prestige" where their synergy with the Scientist (also covered by knowledge, honesty and leadership) should be the lever for the improvement of the Society they both serve.

\section{Conclusion:}

Initiatives on Proposals or Projects with reference to infection issues represent less than 3\% of the total. Of particular relevance in recent years have been those relating to the national plan for the elimination of hepatitis $\mathrm{C}$ and antibiotic resistance.

What is the evolution and presence of "infection in geriatrics" in the scientific literature?

In order to respond to the scientific output on infection in geriatrics, we will proceed to describe the data sources, the search methodology and the findings, in a way deliberately guided by the recommendations of professionals in our workplace libraries.

ScienceDirect [116] is a digital platform that has provided subscription access to a large research database, hosting more than 14 million publications from 3,800 academic journals and 35,000 e-books since 1997. Clinical Key [117], owned by "Elsevier Clinical Solutions", has an intelligent search system, establishing the connection of medical terms with related content. It accesses a collection of resources of clinical guides, algorithms and patient files from Fisterra, the database of monographs of medicines marketed in Spain, the treaties of the Medical Surgical Encyclopaedia, and books and journals in Spanish from the cited publisher. Primo is the discovery/search tool used by the Castilla y León Healthcare Online Library [118] to offer a unique system to access scientific information allowing the recovery of different types of documents such as: journals, books, images, theses, and conference proceedings. Revista Española de Geriatria y Gerontología (The Spanish Journal of Geriatrics and Gerontology) is the publication channel of the Society of the same name, a publication founded in 1966 and the doyenne of the specialty in the Spanish language [119]. MEDES is an initiative of the Fundación Lilly and its database, open and free, contains bibliographical references published since 2001 in a selection of 98 Spanish journals covering 50 subjects in medicine, pharmacy and nursing, published in Spanish, with 100,000 articles [120]. Finally, PubMed is the widely implemented search engine, with free access to the MEDLINE database of citations and abstracts of biomedical research articles, offered by the United States National Library of Medicine and integrating 5,255 worldwide journals since 1966 [121].

The search was conducted with a double strategy: free text and controlled text using "Mesh". In the first strategy, a free text search was conducted in the "Science Direct" and "Clinical Key" databases with the term 'Infection in Geriatrics' resulting in 508 and 1,191 findings respectively. The Primo Search Engine (Castilla y León Online Library) returned a total of 190 results for the same term. Secondly, and also in free text, with the term 'Infection in the elderly', we proceeded to consult Revista Española de Geriatria (the Spanish Journal of Geriatrics), which generated 195 results and Medes (Medicine in Spanish) with 84 results.

The second strategy of controlled text was conducted in the PubMed database, returning the following findings: $<\ln$ fection AND Geriatrics>: 997 results; <Infection AND aged> (people from 65 to 79 years old): 122.698 results and $<$ Infection AND aged OR Aged, 80 and over>: 122.698 results (identical to the previous one). Its development over the last decade has been progressive (from figures close to 4,000 in the 20092010 biennium, to over 5,000 from 2014 to 2017), excluding the year 2018 from the assessment.

We have adopted their classification into thematic areas [122] and the twelve in which 95\% of the results were concentrated are: sepsis and bacteraemia, pneumonia, urinary tract infections, central nervous system infections, endocarditis, prosthetic infections, skin infections, gastrointestinal infection, HIV infection, fever of unknown origin, multi-resistance and vaccinations.

\section{Conclusion:}

The scientific output on infections in the elderly, calculated by different databases, has been increasing in the last decade.

How do the problems of the elderly impact on the mainstream media? How should the media contribute to the reduction of infection in the elderly?

\section{Presentation:}

The impact of the problems of the elderly in the media is 


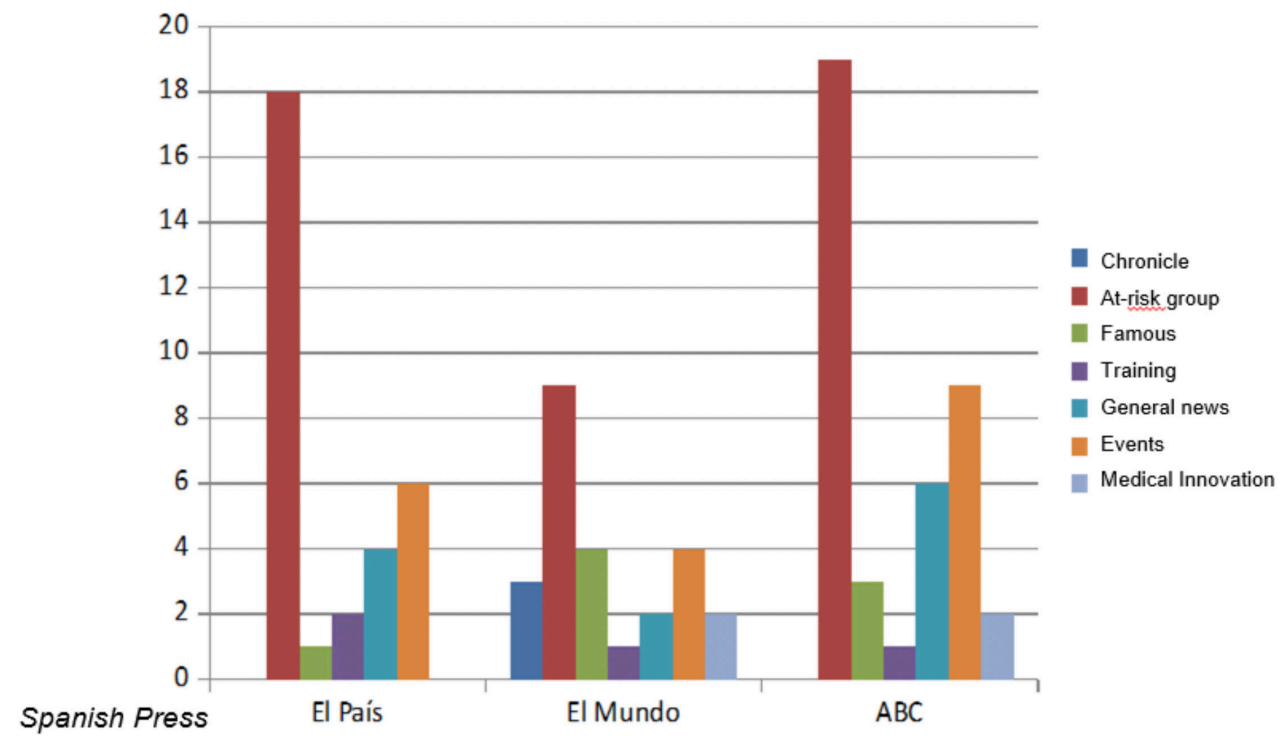

Figure $1 \quad$ Citations regarding "infections" in the "elderly" in 3 major general journals of Spain

limited, deficient, incomplete, unfocused, out of context, stereotyped and with a not particularly constructive, realistic or objective bias.

The elderly are invisible in the media and when they appear, the content relating to them is characterised by simplification, victimhood, dramatization and superficiality.

The image that the media convey of old age is linked to inactivity, unproductiveness, seniority, illness, dependence and deterioration.

Old age and its problems, circumstances, needs and contributions, as a social agent and subject, are not among the priorities and themes of general media planning.

Other groups, sectors, actors or social issues such as immigration, feminism, equality, children, domestic violence, NGOs and their services, new technologies and their advantages, effects and risks, harassment in all its forms, health and sanitation, or scientific advances have much more visibility, relevance, monitoring, currency and presence in the media.

The problems related to a stage of life that we can place at around 80 years provoke a disinterest and sidelining in the information and journalism that only is unblocked in the face of news related to events, diseases, negative or sensationalist facts or anecdotes, offering a fixed, unmoving and old-fashioned image of a sector of the population that, nevertheless, is increasing due to the increase in life expectancy.

In a world where the 21st century grants youth and technology all the plaudits as to what is interesting and important, whether in the press, television, radio, websites or social networks, ageing and old age, as a concept, social and population sector, and newsworthy subject, are moved to a second or third tier on the podium of current affairs and information.
As a small demonstration of this paradox -the contrast between the rising presence of the elderly in society and their lukewarm representation in the media-, we offer a chart with a comparison of publications on the websites of three generalist newspapers, "El Pais", "El Mundo" and "ABC", between the years 2016-2018, with the search for "elderly" and "infection" as key words. A total of 96 news items are recorded that mention the subject studied (figure 1).

This is little news, and in most cases linked to events and to the elderly as a risk group.

This sample would require further media analysis to ratify this tendency in the treatment of the problems of the elderly and the infections they suffer, but it serves as the tip of the iceberg of relegation, insensitivity and atrophy in news treatment.

Since the onset of the economic crisis in 2008, the number of dedicated journalists specialising in social and health issues has been substantially reduced in order to divert manpower and resources mainly to political and economic content.

If, in this situation, health, science and social issues have been scaled down and cut back in the operation of the media, the elderly, as journalistic content, have been pushed to the very margins of the newsrooms with complete normality; with no agenda, no specialists, no briefings, no planning, no contextualization; to see themselves as mere circumstantial, inconsequential, occasional content, with a light, sometimes frivolous treatment, lacking depth and sensitivity; building a narrative of topics, irrelevance and disconnection from their value and presence in society.

This media portrayal of the elderly is in contrast to the ageing of the population, where reliable and accurate statistics 
point to a doubling of the number of older people by 2050.

The data show that in 1960 in Spain, there were 6.7 million children under 10 years and 0.4 million people over 80 years, in 2015 the number of children under 10 had fallen to 4.6 million, and over 80 risen to 2.7 million; by 2050 the trend becomes even more acute, with under 10 years predicted at 3.8 million, and over 80, 6.2 million $[123,124]$.

Globally, in the century from 1950 to 2050, total population will triple; the population over 60 will grow by a factor of 10; and the population over 80 by a factor of 28 , this last group going from 14 million in 1950 to 386 million in 2050.

If information concerning and affecting the elderly continues to be ignored, marginalised and simplified in the media, they will neglect and fail in their mission of gathering information, analysis, data and opinions from a sector of the population with enormous influence on the life and events of a country. Without rigorous, truthful, balanced, comprehensive and complete information on the phenomenon of old age, the view and expression of reality will be distorted, fragmented and fractured.

To help reduce infection in the elderly, the media must take several steps beforehand and activate new information strategies and actions $[125,126]$.

Review and reformulation of the contents for current events, relevance and interest agendas. The first step is to place general social and health issues on the same level of importance as national or international political, economic or sports information, with the consequent allocation of space, dedication and resources.

Enhancement of content for the elderly in social and health information. Within the social and health content, the news of the old and elderly must be equated in relevance, dedication, selection, monitoring and treatment to other issues related to this journalistic field, with emphasis on the quantity and quality of the information, from the rigour, planning and contextualization to gather studies and data, human stories, opinions, difficulties and needs, social influence, contributions, and challenges in this sector of the population.

The aim is to offer a complete, balanced, objective and true vision of their reality, their contributions, their heterogeneity, their variety, their complexity, their evolution and their demands and needs.

The problems arising from the increase in age, health, coexistence and economic situation, as well as cultural, sociological, family and psychological aspects, must be approached with an informational style and treatment where ageing is considered from the standpoint of normality in life, with its ups and downs, and not as a hindrance, obstacle or inappropriate or unsustainable expense.

The social and cultural role of the elderly, their knowledge and experience, their skills and abilities, should be valued as useful and enriching elements to society.

Promotion of health and sanitation information in the elderly. The next step for the media, once the general in- formation on the elderly and very elderly has been strengthened, is to promote health and healthcare information in relation to this sector of the population.

In this context, the media would be in a position to treat and report, with much higher presence and representation criteria than at present, on the infections of the elderly within the framework of their health and well-being.

It is very difficult to reach this third step without the two previous actions, since the handling of a health problem such as infection in the elderly by the media requires a commitment and responsibility in several phases that is part of a comprehensive strategy to provide a journalistic treatment of their problems on a par with their representation and contribution to society.

It is necessary to present older people and the elderly removed from the clichés and stereotypes that link them directly and almost solely to the events, the deterioration of their health, family dependence or the hindrance or burden of their role and function in society.

It is necessary to offer complete and balanced information in which tasks such as interest in culture, modernity, the future, technology or travel; their capacity to lea in civil society, family, business or education; their initiative in domestic and community tasks; their political or social contributions; or their skills in the practice of sport are inherent. In short, to show their vitality, enthusiasm, enterprise, activity, determination, solidarity or collaboration, beyond their problems or difficulties, which must also be reflected and analysed.

It should not be forgotten that though the generation of elderly people now over 75/80 years old may have a more traditional, reserved and passive profile in certain cases -by no means in all-, the new generation of elderly people forecast for 2050, where their number will rise greatly, will experience a huge change with regard to the distorted image of the elderly today.

\section{Conclusion:}

The information that the general media dedicates to the problems of the elderly is minimal, distorted and biased. It is full of clichés and stereotypes that link them directly and almost exclusively to events, the deterioration of their health, family dependency or the hindrance or burden of their role and function in society. Information on infections in this population group is even more scarce.

Does the pharmacist, whether in the hospital or in the community, have a role controlling inappropriate antibiotic therapy in the elderly? What about vaccination?

\section{Presentation:}

The answer is YES, without a doubt [95, 127-138]. The reasons are detailed below: Studies conducted following scientific evidence criteria in recent years show that pharmaceutical care and the intervention of the pharmacist improve the overall quality of patient care, while the WHO itself states that 
pharmacists "contribute decisively to the rational use of medicines". The decision on how to treat a given infection correctIy with the most appropriate antimicrobial requires detailed knowledge of microbiological, clinical and pharmacological issues, but the causes of an optimal result go beyond this and extend to the so-called non-pharmacological basis, among which the behaviours of doctors, patients and pharmacists, as well as the relationships between them, play a fundamental role. The pharmacist is one of the apices of the so-called "human factor triangle" (made up of doctor-patient-pharmacist), a mirror image of the famous "Davis triangle" (antimicrobial-microorganism-host).

Currently, pharmaceutical care aims to obtain the maximum clinical benefit from medicines and to achieve the lowest possible risk in the use of those medicines, which entails the identification, resolution and prevention of medication-related problems (MRP): adverse drug reactions (ADR), drug-drug interactions (DDI), deficiencies in physician prescription, errors in the use of medication by the patient and breaking the vicious circle so frequent in the use of antimicrobials formed by self-medication - noncompliance - storage.

Pharmaceutical care is a process, which includes different stages: active dispensation (supply, delivery, dispatch >>> assistance, help, care), educational advice (health advice in response to a consultation/problem or instruction on the acquisition of a medicine) and pharmacotherapeutic follow-up (documentation and registration of the activity).

As far as the hospital pharmacist is concerned, it must be said that they not only participate actively in the rational use of antimicrobials from their role as an active member of the pharmacy commission and the antimicrobial committee, but also get involved on a daily basis in the prudent and correct application of antimicrobial therapy, in order to obtain the most beneficial result from the clinical point of view and the most efficient from the pharmaco-economic point of view. This implies that: the appropriate antimicrobial has been prescribed in accordance with a correct diagnosis and the special characteristics of the elderly patient, it is dispensed under the proper conditions, administered at the indicated doses, at the intervals and for the period intended, it is used with the lowest possible cost, in such a way as to prevent or minimise the development of bacterial resistance and it achieves the desired therapeutic objective.

In short, both the community and the hospital pharmacist as first-level health agents play a central role in the field of therapeutic adherence and rational use of antimicrobials, proposing their use in terms of quality of treatment and considering antimicrobials not only by virtue of the active ingredient contained in the corresponding pharmaceutical specialty, but also in terms of useful information ("software"). Furthermore, both must take into account that antibiotics and vaccines are the paradigm of societal treatment and the treatment or non-treatment of an individual can affect the community [139].

\section{Conclusion:}

The answer is YES, without a doubt. Studies conduct- ed following scientific evidence criteria in recent years show that pharmaceutical care and the intervention of the pharmacist improve the overall quality of patient care, while the WHO itself states that pharmacists "contribute decisively to the rational use of medicines".

What is the administration doing and what can it do to reduce these problems? From an educational point of view? From the legislative-regulatory point of view?

\section{Presentation:}

In order to reduce these problems, the State Administration must, among other things, launch:

1. Prevention strategies and measures to control the transmission of the infection.

2.- Vaccination programmes in the elderly.

3.- Training and information programmes for health professionals, particularly in the area of rational use of antimicrobials and promotion of the use of appropriate definitions $[140,141]$.

4.- Guidelines or recommendations on recommended antimicrobial treatments for the most prevalent infections in different healthcare settings.

5.- Standards for therapeutic effort in advanced and terminal phases of illness.

From an educational point of view, it is up to the Administration:

1.- To encourage "Health Schools" that educate the population on self-care, stimulating healthy living habits and eliminating toxic habits.

2.- To promote information on predisposing risk factors for infection by multi-resistant microorganisms.

3.- To educate patients on the proper use of antimicrobials in primary care settings

4.- To educate on health and the use of antimicrobial agents from the pharmacy offices.

5.- Promote information on the disposal of surplus antimicrobials ("SIGRE Points").

From the legislative-regulatory point of view, the administration must:

1.- Promote and maintain a Reporting-Communication System for some infectious diseases (EDO, VIRAS, etc.), subdivided by age groups.

2.- Mandate the implementation of a health protection system consisting of a Pest Control Plan, an Urban, Sanitary, Bio-sanitary and Cytotoxic Waste Management Programme and a Hygiene, Food Safety and HACCP System.

3.- Legislate on Occupational Risk Prevention, obliging healthcare workers to protect themselves against certain infections to prevent them from acting as a source of contagion or a vehicle for the transmission of the infection.

4.- Regulate the implementation of measures or precau- 
tions for the prevention and control of Healthcare Associated Infections (HAls).

Some examples of the above are programmes such as: "Antibiotics: Take them seriously" (2017); the "World Antibiotic Awareness Week" (2018); the "European Antibiotic Awareness Day" (2018). A National Plan against Antimicrobial Resistance (PRAN) run by the Spanish Agency of Medicines and Health Products (AEMPS) is essential [142, 143-147].

\section{Conclusion:}

The administration has a constitutional mandate to promote health, which is of particular concern to groups as vulnerable as the elderly. Among the measures to be implemented, those of an educational nature are especially necessary, both for patients and for their caregivers and healthcare personnel. From a legislative-regulatory point of view, we cannot forget that Spain has one of the best health systems in the world.

What is the role of nursing in managing and reducing infection in the elderly? How does the training of the caregiver affect this?

\section{Presentation:}

Nurses develop preventive interventions, participate in the monitoring, control, therapeutic adherence and care plan when the infection is established. These competencies are developed inside and outside of healthcare institutions. In the home setting, the focus is on education and providing support for safe practices [148-151].

Professionals, caregivers and elderly people have to distinguish modes of transmission, identify risk factors and susceptible people who may become reservoirs or constitute a vehicle of contagion and understand basic protective and barrier measures.

The simplest, most effective and universal procedure is hand hygiene. The World Health Organization identifies five key times for washing: before and after contact with the person, before performing a clean/septic task, after the risk of exposure to body fluids, and after contact with the patient's environment [152-154].

When hygiene guidelines are given, it is worth noting other times: before, during and after handling or preparing food, before eating, before giving medication, before and after treating a wound or handling clinical devices, after using the bathroom and after handling used clothing, whether personal, bath or bedding, diapers or waste. After washing, it is important to dry the hands.

Personal hygiene and topical hydration are other prevention strategies. The skin constitutes a natural protective barrier and is particularly labile in the elderly. Its daily care guarantees its integrity and protects it from external assault. This includes body hygiene and protective measures aimed at moisture control and injury prevention. Some studies highlight the importance of oral hygiene in relation to respiratory diseases [155].
Another precaution is the sanitation of the space in which the elderly person stays so as to make it a healthy environment, including daily cleaning of surfaces, objects and utensils, ventilation, illumination preferably with natural light, and appropriate environmental temperature and humidity [156].

The tendency to unbalanced diets, malnutrition and low fluid intake increases susceptibility to infection. It is essential to promote healthy lifestyles and to provide structured plans for eating, drinking and exercise adapted to individual needs taking preferences and health problems into account [157162].

Another strategy is the vaccination of the elderly and carers, adjusted for age, particular situation and the approved schedule in each autonomous community [163].

Although infectious diseases in the elderly do not always have obvious signs and symptoms, the caregiver detects changes in their baseline situation that may lead to a suspicion of the presence of an infectious process, so education should be provided on how to proceed in the light of this suspicion and what to do when it is confirmed.

Finally, it is necessary to emphasise the effective management of treatment (dose, administration and side effects) and periodically monitor therapeutic adherence, avoiding self-medication, in order to achieve the optimal effects of non-pharmacological and pharmacological measures, so as to enable prevention, delay deterioration, recover or maintain health [164].

\section{Conclusion:}

Nurses develop interventions for prevention, monitoring and therapeutic adherence control, participating in the care plan for infection in the elderly.

The implementation of many of the health promotion and care plans and regulations is the direct responsibility of the nursing profession.

\section{How do senior citizens' associations deal with this problem?}

\section{Presentation:}

The issue of health is a priority for the elderly and infection in particular is one of the most frequent causes of morbidity and mortality in the elderly, as has already been mentioned.

Elderly associations have traditionally focused on chronic rather than acute diseases and therefore have a huge role to play in this area.

It is the mission of the elderly associations to encourage and promote the residence of the elderly in a family and social environment that is agreeable to them. It is well known that an older person who lives comfortably at home with family members has less risk of acquiring infections than one who lives alone.

In the case of the elderly institutionalised in residences, the elderly associations have the mission to ensure the quality 
of these institutions, that they are equipped with the appropriate medical, nursing and social services and that a systematic accreditation of these services is achieved. Ideally, these centres should have very significant prevention measures in place and should work closely, on the one hand, with the primary care physicians responsible for the patients, and on the other hand, with the reference hospitals to which the patients have to be transferred at some point.

Elderly associations must continue to work to improve the care of the elderly in emergency departments, not only from a technical point of view, but also by ensuring the agility of the assessment and dignified conditions for the elderly in these departments.

Finally, the elderly who are hospitalised are patients who require very rapid mobilization, avoidance of exposure to multi-resistant microorganisms and the fastest possible transfer back to where they came from. Elderly associations promote the provision of geriatric beds and services in all hospitals, where structures and organisations are set up specifically to serve the needs of elderly patients with a comprehensive idea of their care.

As we have mentioned, prevention is better than cure, and in that sense, the elderly associations can play an important role in emphasizing to the authorities, to the groups of affected people and to healthcare personnel the importance of promoting vaccination campaigns [86]

In short, associations for the elderly, whether they are focused on health or not, can play a very positive role that is often overlooked when it comes to improving health. They could work, if possible, promoting and propagating vaccination campaigns. They could also contribute more than they do to other forms of health education, from those oriented towards nutrition or physical activity, to those focused on fighting toxic habits or reporting abuse. All this is of general interest, as well as directly and indirectly affecting the field of infectious pathology.

Following the recommendations of the Expert Consensus on frailty in the elderly, active ageing and drug screening in polymedicated patients are important in preventing infections in these patients.

\section{Conclusion:}

Elderly associations must play a major role in demanding quality care policies for elderly patients, both in the fields of prevention and treatment. Target areas for intervention are the home environment, the outpatient system, nursing homes, hospital emergency departments and hospital care.

Patient associations can contribute more than they do to other forms of health education, from those oriented towards nutrition or physical activity, to those focusing on combating toxic habits or reporting abuse.

What ethical aspects would you highlight in all these problems?

\section{Presentation:}

The great social esteem that existed in ancient cultures for the elder of the group or tribe is well known. He was not only the oldest person but also the biological father, the political leader and, in many cases, the religious authority. And, as anthropologists have pointed out more than once, the "hard disk" of the community, aware of past events of which the younger generations are not, thereby bringing the social group together and giving it its own identity. Hence, the elders were not only respected but highly valued and even revered. It is enough to open the books of the Bible, for example, to find testimonies of this. Its pages over and over again reverential respect for the elder, applying such venerable terms as "Patriarch". The Bible attributes an extraordinary longevity to the first patriarchs (Gen 5; 11,10-26), and even to the later patriarchs, like Abraham (Gen 17,1.17; 18,12) and Moses (Dt 31,1;34,7), and to the prophets, it is difficult to represent them as young people. Respect leads the bible authors to attribute centuries-long lives to them. Longevity is a sign of their wisdom. The so-called wisdom literature bears good witness to this veneration for the elderly. In the book of Ecclesiasticus we read:

In your youth you did not gather.

How will you find anything in your old age?

How appropriate is sound judgment in the grey-haired,

and good counsel in the elderly!

How appropriate is wisdom in the aged,

understanding and counsel in the venerable!

The crown of the elderly, wide experience;

their glory, the fear of the Lord. (Sir 25,3-6)

The theme of the wisdom and prudence of the elderly is repeated:

For the age that is honourable comes not with the passing of time,

nor can it be measured in terms of years.

Rather, understanding passes for grey hair,

and an unsullied life is the attainment of old age. (Wis 4:8-9)

And the book of Proverbs:

Grey hair is a crown of splendour;

it is attained in the way of righteousness. (Prov 16:31).

The contrast between the ancient civilization of Israel and the archaic Greek culture, as presented in the Homeric poems, is surprising. It is difficult to imagine Ulysses, Hector or Achilles as elders, even though in those poems there are also venerable subjects such as Menelaus, Agamemnon and Priam. The contrast between Agamemnon and Achilles is particularly significant, for the poet paints the former as an ambitious and selfish man, with an excessive ego who confronts Achilles, his best warrior, again and again. Heroes, those beings that the Greeks considered perfect and semi-divine, are by necessity young and in the fullness of their life force. In Greek statuary 
it is impossible to see the decrepitude of the elderly person represented. The poet Menander coined a sentence that soon became famous and that Plautus translated into Latin: Quem di diligunt, adulescens moritur, "those loved by the gods die young" (Bacchides, 816-817). Perfection is in youth, and old age is almost embarrassing. Aristotle says that "disease is an acquired old age, old age a natural disease" (Gen. An. 784 b 33-4).

It was important to remember this about the attitude of our culture, the western one, towards the elderly. They've never been held in high esteem. Moreover, we can be seen that this esteem has been decreasing over time. This is demonstrated by the words we use to refer to this age group. "Viejo" (old) comes from the Latin vetus, the opposite of novus, both of which are terms that were designating things, not people. For people, the correct terms were senex and its opposite iuvenis. From senex comes our word "senescence", only used in a very limited sense today. Cicero wrote a dialogue De Senectute, using the correct term in his language. Though, in the various Spanish editions that exist, the translation is invariably Sobre la vejez. (On Old Age). Old age is not only an improper term, but also a derogatory one. No one sees it that way anymore, because they don't know about this process. But the transition from one term to another is an evident sign of the devaluation that the figure of the elder has undergone in Western culture, even though it was originally already much lower than that of other cultures.

If we add to this the spectacular increase in life expectancy at birth in the last century, it turns out that this devalued period, which until the beginning of the 20th century was almost anecdotal in the life of Western society (it should be remembered that life expectancy at birth in Spain had been stable at 25-30 years from the Neolithic revolution to the end of the 19th century), has become a period of no lesser and sometimes greater duration than the active life of a person. So much so that human life today can very well be divided into three 30-year periods, the first of which is devoted to vocational training, the second to production, and the third.. it is not very clear to what, among other things, because the training we were given in the first 30 years was aimed at being productive in the second phase, but we were never educated for the "third age".

The third and final phase of life, which today has an average duration of 30 years, is a continuous source of problems. It is, at least, in the economic order, as the present pension system seems difficult to maintain, and will be impossible in the near future. But, as important as this is, that's not the biggest problem. The most serious issue is that we have condemned the elderly to being a "passive class", whom INSERSO (The Institute for the Elderly and Social Services) has to ferry from one place to another in order to at least distract them. There is talk of discrimination and abuse of the elderly. In my opinion, the greatest discrimination is this, the fact that the elderly have been deprived of their own role in society; or, to put it another way, the total absence of what I have been calling the "third age culture" for some time [165]. Yes, third age culture. The third age has its own culture, distinct from the second age.
Modern systems of work organisation have made "efficiency" a major objective of the culture of the second stage of life. There is no doubt that in Spain, for example, efficiency has increased three or fourfold in the last half century. And here is the origin of the problem. What do you do when you are no longer "efficient", at least in the way the economy defines efficiency?

Efficiency is a value that belongs to the category of socalled "instrumental values", "reference values" or "technical values". They are so called as they have no value in themselves, but only in reference to something else or another value. Let's think, for example, of a drug. There is no doubt that it has value, at least financially. Its most valuable asset is to relieve a symptom or cure a disease. If it wasn't good enough, we'd say "it's not good enough", and we wouldn't pay for it. This means that the value of the drug is in reference to something other than itself, such as well-being, health, life, etc. This happens to all technical instruments. If we were to find a more effective or less expensive drug, there is no doubt that we would choose it, because this is what efficiency is about: the cost/benefit ratio. Efficiency is the unit of measurement for instrumental values.

The problem is that not everything is instrumental. If they are always in the service of others, it means that these others must stand on their own, otherwise we fall into an infinite regression. These are called "intrinsic values" or "fundamental values". They are the most important in life. They are essential values, values that have worth in their own right, without reference to others. Think, for example, of dignity. Or many others, such as health, life, beauty, well-being, justice, solidarity, etc. These are all intrinsic values. Without them, life is meaningless [165]. Furthermore, they have the characteristic of not being measured in monetary units, nor is efficiency a criterion. "Health is priceless" it has always been said; "true love is neither bought nor sold"; "only the foolish confuses value and price" said Antonio Machado. And the list could go on [166].

We can now understand the importance of promoting a culture of old age. During our working life there is no doubt that the fundamental criterion must be efficiency, and therefore economy. But that is, at the same time, the least human part of life. The day is not far off when that part of our existence can be transferred to the robots. And the problem arises: What will we humans do then? Will we have anything to do?

Older people have a fundamental mission in our society, and that is to take charge of promoting intrinsic values and passing them on to younger generations. It's not all about economics. It's not all about efficiency. There are other values, which moreover are the most important, the most human.

\section{Conclusion:}

Promoting a new culture of the elderly should lead us to avoid not only the discrimination that has occurred throughout Western culture, and particularly in recent centuries, but also to give impetus to the promotion of intrinsic values, the most humane, the most important in the lives of individuals and societies. This is the very im- 
portant active role that members of the third age have been entrusted with, given that in our culture the second age is obsessively consumed by the promotion of economic efficiency.

Does this matter for the control of infection in the elderly? As has already been said in previous interventions, the dynamic, active elderly, who feel that they have a mission to fulfil in society, are undoubtedly in a better position to avoid infections and to combat them when they do occur. It is not true that, as Aristotle said, old age is a "natural disease". There are many reasons to claim that it is not merely a part of life, but in many ways the most important. And it will be even more so in the future.

\section{CONFLICTS OF INTEREST}

The authors declare that they have no conflict of interest.

\section{FUNDING}

This publication has been funded by GlaxoSmithKline.

\section{REFERENCES}

1. Beard JR, Officer $A$, de Carvalho IA, Sadana R, Pot AM, Michel JP, et al. The World report on ageing and health: a policy framework for healthy ageing. Lancet. 2016;387(10033):2145-54. DOI: 10.1016/ s0140-6736(15)00516-4

2. Beard J, Officer A, A. C. World report on ageing and health. World Health Organization; Geneva. http://www.who.int/ageing/publications/world-report-2015/en/

3. Fernández Muñoz JN, Vidal Domínguez MJ, Labeaga Azcona JM, Casado Durandez P, Madrigal Muñoz A, López Doblas J, et al. Las personas mayores en España. Datos estadísticos estatales y por Comunidades Autónomas Ministerio de Sanidad, Servicios Sociales e Igualdad Secretaría de Estado de Servicios Sociales e Igualdad Instituto de Mayores y Servicios Sociales 2016.

4. Pawelec G. Hallmarks of human "immunosenescence": adaptation or dysregulation? Immun Ageing. 2012;9(1):15. DOI: 10.1186/17424933-9-15

5. Pawelec G. Age and immunity: What is "immunosenescence"? Exp Gerontol. 2018;105:4-9. DOI: 10.1016/j.exger.2017.10.024

6. Plewa MC. Altered host response and special infections in the elderly. Emerg Med Clin North Am. 1990;8(2):193-206.

7. Ribera Casado JM. Principios básicos sobre las infecciones en patología geriátrica. In: Gregorio JRCyPG, editor. Patología infecciosa en geriatría Madrid: Editores Médicos SA; 1992. p. 10-23.

8. Norman DC. Clinical Features of Infection in Older Adults. Clin Geriatr Med. 2016;32(3):433-41. DOI: 10.1016/j.cger.2016.02.005

9. Norman DC, Toledo SD. Infections in elderly persons. An altered clinical presentation. Clin Geriatr Med. 1992;8(4):713-9.

10. Norman DC. Pneumonia in the elderly: empiric antimicrobial therapy. Geriatrics. 1991;46(12):26-32.
11. Norman DC. Special considerations for antimicrobial therapy in the elderly. Geriatrics. 1989;44 Suppl A:23-7.

12. Norman DC, Grahn D, Yoshikawa TT. Fever and aging. J Am Geriatr Soc. 1985;33(12):859-63.

13. Norman DC, Yoshikawa TT. Intraabdominal infection: diagnosis and treatment in the elderly patient. Gerontology. 1984;30(5):327-38. DOI: $10.1159 / 000212652$

14. Norman DC, Yoshikawa T. Intraabdominal infections in the elderly. J Am Geriatr Soc. 1983;31(11):677-84.

15. Montoya A, Cassone M, Mody L. Infections in Nursing Homes: Epidemiology and Prevention Programs. Clin Geriatr Med. 2016;32(3):585-607. D0I: 10.1016/j.cger.2016.02.004

16. Martin-Sanchez FJ, Julian-Jimenez A, Candel Gonzalez FJ, Llopis Roca F, Martinez Ortiz de Zarate M, Gonzalez Del Castillo J. [Profile and initial management of infection in elderly patients in an Emergency Department]. Rev Esp Geriatr Gerontol. 2017;52(1):914. DOI: 10.1016/j.regg.2016.02.006

17. Chou HL, Han ST, Yeh CF, Tzeng IS, Hsieh TH, Wu CC, et al. Systemic inflammatory response syndrome is more associated with bacteremia in elderly patients with suspected sepsis in emergency departments. Medicine. 2016;95(49):e5634. DOI: 10.1097/ md.0000000000005634

18. Chou MY, Chou SL, Tzeng YM, Chen LK, Oliver D, Yen DH, et al. Emergency department (ED) utilization of oldest old men in a veterans care home in Taiwan. Arch Gerontol Geriatr. 2009;48(2):25862. D0I: 10.1016/j.archger.2008.02.001

19. Matthews SJ, Lancaster JW. Urinary tract infections in the elderly population. The Am J Geriatr Pharmacother. 2011;9(5):286-309. DOI: 10.1016/j.amjopharm.2011.07.002

20. Detweiler K, Mayers D, Fletcher SG. Bacteruria and Urinary Tract Infections in the Elderly. Urol Clin North Am. 2015;42(4):561-8. DOI: 10.1016/j.ucl.2015.07.002

21. Henig O, Kaye KS. Bacterial Pneumonia in Older Adults. Infect Dis Clin North Am. 2017;31(4):689-713. D0I: 10.1016/j.idc.2017.07.015

22. Artero A, Esparcia A, Eiros JM, Madrazo M, Alberola J, Nogueira JM. Effect of Bacteremia in Elderly Patients With Urinary Tract Infection. Am J Med Sci. 2016;352(3):267-71. DOI: 10.1016/j.amjms.2016.05.031

23. Silverman M, Povitz M, Sontrop JM, Shariff SZ. Antibiotic Prescribing for Nonbacterial Acute Upper Respiratory Infections in Elderly Persons. Ann Intern Med. 2017;167(10):758-9. D0I: 10.7326/1170438

24. Ye C, Zhu W, Yu J, Li Z, Fu Y, Lan Y, et al. Viral pathogens among elderly people with acute respiratory infections in Shanghai, China: Preliminary results from a laboratory-based surveillance, 20122015. J Med Virol. 2017;89(10):1700-6. DOI: 10.1002/jmv.24751

25. Kestler M, Munoz $P$, Mateos $M$, Adrados D, Bouza E. Respiratory syncytial virus burden among adults during flu season: an underestimated pathology. J Hosp Infect. 2018;100(4):463-8. DOI: 10.1016/j.jhin.2018.03.034

26. Falsey AR, McElhaney JE, Beran J, van Essen GA, Duval X, Esen M, et al. Respiratory syncytial virus and other respiratory viral infections 
in older adults with moderate to severe influenza-like illness. J Infect Dis. 2014;209(12):1873-81. DOI: 10.1093/infdis/jit839

27. Asempa TE, Nicolau DP. Clostridium difficile infection in the elderly: an update on management. Clin Interv Aging. 2017;12:1799-809. DOI: $10.2147 /$ cia.S149089

28. Redelings MD, Sorvillo F, Mascola L. Increase in Clostridium difficile-related mortality rates, United States, 1999-2004. Emerg Infect Dis. 2007;13(9):1417-9. D0I: 10.3201/eid1309.061116

29. Friedman-Korn T, Livovsky DM, Maharshak N, Aviv Cohen N, Paz K, Bar-Gil Shitrit A, et al. Fecal Transplantation for Treatment of Clostridium Difficile Infection in Elderly and Debilitated Patients. Dig Dis Sci. 2018;63(1):198-203. DOI: 10.1007/s10620-017-4833-2

30. Girotra M, Garg S, Anand R, Song Y, Dutta SK. Fecal Microbiota Transplantation for Recurrent Clostridium difficile Infection in the Elderly: Long-Term Outcomes and Microbiota Changes. Dig Dis Sci. 2016;61(10):3007-15. DOI: 10.1007/s10620-016-4229-8

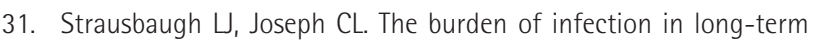
care. Infect Control Hosp Epidemiol. 2000;21(10):674-9. DOI: $10.1086 / 501712$

32. Dwyer $L L$, Harris-Kojetin $L D$, Valverde RH, Frazier JM, Simon $A E$, Stone ND, et al. Infections in long-term care populations in the United States. J Am Geriatr Soc. 2013;61(3):342-9. DOI: 10.1111/ jgs. 12153

33. Stevenson KB, Moore J, Colwell H, Sleeper B. Standardized infection surveillance in long-term care: interfacility comparisons from a regional cohort of facilities. Infect Control Hosp Epidemiol. 2005;26(3):231-8. DOI: 10.1086/502532

34. Koch AM, Eriksen HM, Elstrom $P_{1}$ Aavitsland $P_{1}$ Harthug S. Severe consequences of healthcare-associated infections among residents of nursing homes: a cohort study. J Hosp Infect. 2009;71(3):26974. DOI: 10.1016/j.jhin.2008.10.032

35. Wang L, Lansing B, Symons $K_{1}$, Flannery EL, Fisch J, Cherian $K_{\text {, et }}$ al. Infection rate and colonization with antibiotic-resistant organisms in skilled nursing facility residents with indwelling devices. Eur J Clin Microbiol Infect Dis. 2012;31(8):1797-804. DOI: 10.1007/ s10096-011-1504-7

36. European Centre for Disease Prevention and Control. Protocol for validation of point prevalence surveys of healthcare-associated infections and antimicrobial use in European long-term care facilities - 2016-2017 version 1.1. Stockholm: ECDC; 2016. version 11 Stockholm: ECDC. 2016.

37. Tandan M, Burns K, Murphy H, Hennessy S, Cormican M, Vellinga A. Antimicrobial prescribing and infections in long-term care facilities (LTCF): a multilevel analysis of the HALT 2016 study, Ireland, 2017. Euro surveillance : bulletin Europeen sur les maladies transmissibles $=$ European communicable disease bulletin. 2018;23(46). DOI: 10.2807/1560-7917.Es.2018.23.46.1800278

38. Burns $K_{1}$ Roche F, Donlon S. Healthcare-associated infections and antimicrobial use in long-term care facilities: the Irish experience with the HALT surveys. J Hosp Infect. 2015;89(4):276-80. D0I: 10.1016/j.jhin.2014.12.006

39. Chami K, Gavazzi G, Carrat F, de Wazieres B, Lejeune B, Piette $F_{1}$ et al. Burden of infections among 44,869 elderly in nursing homes: a cross-sectional cluster nationwide survey. J Hosp Infect. 2011;79(3):254-9. DOI: 10.1016/j.jhin.2011.08.003

40. Yuste Marco A. Infecciones en hospitales de larga estancia, centros residenciales y otras unidades geriátricas. Enferm Infecc Microbiol Clin 2003;21: suppl 1:1-4.

41. Beobide Telleria I, Alaba Trueba J, Genua Goena MI, Arriola Manchola $E_{1}$ Iturrioz Arrechea I, Alvarez De Arcaya Vitoria M, et al. [Infection epidemiology in gerontology centres]. Rev Esp Geriatr Gerontol. 2011;46(2):63-7. DOI: 10.1016/j.regg.2010.11.007

42. Serrano $M$, Barcenilla F, Limon $E_{1}$ Pujol M, Gudiol F. Prevalence of healthcare-associated infections in long-term care facilities in Catalonia. VINCat Program. Enferm Infecc Microbiol Clin. 2017;35(8):505-10. DOI: 10.1016/j.eimc.2015.11.011

43. Prevalencia de problemas de salud en la población asignada a atención primaria. Principales resultados. Actualizado el 14 de marzo de 2016. http://www.msssi.gob. es/estadEstudios/estadisticas/ estadisticas/estMinisterio/SIAP/home.htm. [Consultado 20 marzo 2019.].

44. Pujol M, Limon E. Epidemiologia general de las infecciones nosocomiales. Sistemas y programas de vigilancia. Enferm Infecc Microbiol Clin. 2013;31(2):108-13. DOI: 10.1016/j.eimc.2013.01.001

45. Estudio EPINE-EPPS 2017. EPINE-Pint prevalence survey of healthcare-associated infections and antimicrobial use in acute hospitals, ECDC, 2016-2017. Estudio Epine no 28: 1990-2017.

46. Agency for Healthcare Research and Quality. Healthcare Cost and Utilization Project Facts and Figures 2008. Statistics on Hospital-Based Care in the United States. (AHRO). https://www.hcup-us. ahrq.gov/reports/factsandfigures/2008/section1_TOC.jsp

47. US Centers for Disease Control and Prevention. Number, percent distribution, rate, days of care with average length of stay, and standard error of discharges from short-stay hospitals, by sex and age: United States, 2010. https://www.cdc.gov/nchs/data/ nhds/2average/2010ave2_ratesexage.pdf.

48. Spector W, Mutter $R_{1}$ Owens $P_{1}$ Limcango W. Transitions between nursing homes and hospitals in the elderly population, 2009. Healthcare Cost and Utilization Project, Statistical brief \#141, Agency for Healthcare Research and Quality. 2009.

49. Centers for Disease Control and Prevention. https://www.cdc.gov/ nchs/data/series/sr_13/sr13_165.pdf (Accessed on October 07, 2011). 2011.

50. Chelluri L, Grenvik A, Silverman M. Intensive care for critically ill elderly: mortality, costs, and quality of life. Review of the literature. Arch Intern Med 1995;155:1013.

51. Landefeld CS, Palmer RM, Kresevic DM, Fortinsky RH, J K. A randomized trial of care in a hospital medical unit especially designed to improve the functional outcomes of acutely ill older patients.N Engl J Med 1995;332.1338.

52. Saliba W, Fediai A, Edelstein $H_{1}$ Markel A, Raz R. Trends in the burden of infectious disease hospitalizations among the elderly in the last decade. Eur J Intern Med. 2013;24(6):536-40. DOI: 10.1016/j. ejim.2013.06.002

53. Upshur RE, Knight K, Goel V. Time-series analysis of the relation between influenza virus and hospital admissions of the elderly in On- 
tario, Canada, for pneumonia, chronic lung disease, and congestive heart failure. Am J Epidemiol. 1999;149(1):85-92. D0I: 10.1093/ oxfordjournals.aje.a009731

54. Puig-Barbera J, Marquez-Calderon S, Masoliver-Fores A, Lloria-Paes F, Ortega-Dicha A, Gil-Martin M, et al. Reduction in hospital admissions for pneumonia in non-institutionalised elderly people as a result of influenza vaccination: a case-control study in Spain. J Epidemiol Community Health.1997;51(5):526-30. DOI: 10.1136/ jech.51.5.526

55. Puig-Barbera J, Diez-Domingo J, Perez Hoyos S, Belenguer Varea A, Gonzalez Vidal D. Effectiveness of the MF59-adjuvanted influenza vaccine in preventing emergency admissions for pneumonia in the elderly over 64 years of age. Vaccine. 2004;23(3):283-9. DOI: 10.1016/j.vaccine.2004.07.017

56. Martin-Sanchez FJ, Fernandez Alonso C, Gil Gregorio P. Puntos clave en la asistencia al anciano fragil en Urgencias. Med Clin (Barc).2013;140(1):24-9. DOI: 10.1016/j.medcli.2012.04.009

57. Julian-Jimenez A, Supino M, Lopez Tapia JD, Ulloa Gonzalez C, Vargas Tellez LE, Gonzalez Del Castillo J, et al. Sepsis in the emergency department: key points, controversies, and proposals for improvements in Latin America. Emergencias. 2019;31(2):123-35.

58. Tomás $S$, Chanovas M, Roqueta $F$, Alcaraz J, Toranzo T, EVADUR. Gdt. Grupo de trabajo EVADUR: Eventos adversos ligados a la asistencia en los servicios de urgencias de hospitales españoles. Emergencias. 2010;22:254-8.

59. Ovens H. Saturación de los servicios de urgencias. Una propuesta desde el Sistema para un problema del Sistema. Emergencias. 2010;22: 244-6.

60. Flores CR. La saturación de los servicios de urgencias: una llamada a la unidad. Emergencias. 2011;234: 59-64.

61. Fernández C, González del Castillo J, González Armengol Juan Jorge. M-SFJ. La detección del paciente anciano frágil en el área de observación de urgencias. Aten Primaria. 2011;43:449.

62. Martínez Ortiz de Zárate M, González Del Castillo J, Julián Jiménez A, Piñera Salmerón P, Llopis Roca F, Guardiola Tey JM, et al. Estudio INFURG-SEMES: epidemiología de las infecciones atendidas en los servicios de urgencias hospitalarios y evolución durante la última década. Emergencias. 2013; 25:368-78.

63. The Core Curriculum and Educaton Committee for the International Federation for Emergency Medicine. Modelo de Plan de Estudios de la Federación Internacional de Medicina de Emergencias para los Especialistas de Medicina de Urgencias y Emergencias. Emergencias 2011; 23:394-9.

64. Ministerio de Sanidad Servicios Sociales e Igualdad. Informe anual del sistema nacional de salud (SNS). 2018. Disponible en: https:// www.mscbs.gob.es/estadEstudios/estadisticas/sisInfSanSNS/tablasEstadisticas/InfAnSNS.htm.

65. Llor Vilà C, Moragas Moreno A, Hernández Anadón S. Infecciones del tracto respiratorio. AMF. 2011;7:124-75.

66. Estella A, Marchante C, Cobos J, Navarro C. [Infection in the elderly patient. Consensus recommendations for management in the Emergency Department]. Rev Esp Geriatr Gerontol. 2016;51(2):1201. DOI: $10.1016 /$ j.regg.2015.07.013
67. Giménez 0. Los problemas de salud más frecuentes en atención primaria 7DM. 2016;867:Marzo-Abril.

68. Graziani Noriega D, A. AL. Protocolo diagnóstico y tratamiento empírico en urgencias de las infecciones broncopulmonares en los ancianos y en pacientes inmunosuprimidos. Medicine (Madrid). 2018;12:3789-93.

69. Cañada Merino J L. Actualización en Infecciones y Atención Primaria. Fármaco salud com. 2016.

70. Redondo E, Rivero I, Vargas D, et al. Vacunación frente a la Neumonía adquirida en la comunidad del adulto. Posicionamiento del Grupo de Neumoexpertos en Prevención. Semergen. 2016;42:46475.

71. Lim CJ, McLellan SC, Cheng AC, Culton JM, Parikh SN, Peleg AY, et al. Surveillance of infection burden in residential aged care facilities. Med J Aust. 2012;196(5):327-31. DOI: 10.5694/mja12.10085

72. Izaias EM, Dellaroza MS, Rossaneis MA, Belei RA. Custo e caracterizacao de infeccao hospitalar em idosos. Cien Saude Colet. 2014;19(8):3395-402. doi: 10.1590/1413-81232014198.12732013.

73. Cilloniz C, Rodriguez-Hurtado D, Torres A. Characteristics and Management of Community-Acquired Pneumonia in the Era of Global Aging. Med Sc. (Basel, Switzerland). 2018;6(2). DOI: 10.3390/medsci6020035

74. Izquierdo C, Oviedo M, Ruiz L, Sintes X, Vera I, Nebot M, et al. Influence of socioeconomic status on community-acquired pneumonia outcomes in elderly patients requiring hospitalization: a multicenter observational study. BMC Public Health. 2010;10:421. D0I: 10.1186/1471-2458-10-421

75. Welte T, Torres A, Nathwani D. Clinical and economic burden of community-acquired pneumonia among adults in Europe. Thorax. 2012;67(1):71-9. DOI: 10.1136/thx.2009.129502

76. Bilal $U$, Cainzos-Achirica M, Cleries M, Santaeugenia S, Corbella $X_{1}$ Comin-Colet J, et al. Socioeconomic status, life expectancy and mortality in a universal healthcare setting: An individual-level analysis of >6 million Catalan residents. Prev Med. 2019;123:91-4. DOI: 10.1016/j.ypmed.2019.03.005

77. Bartolome M, Almirall J, Morera J, Pera G, Ortun V, Bassa J, et al. A population-based study of the costs of care for community-acquired pneumonia. Eur Resp J. 2004;23(4):610-6.

78. Sanz F, Morales-Suarez-Varela M, Fernandez E, Force L, Perez-Lozano MJ, Martin V et al. A Composite of Functional Status and Pneumonia Severity Index Improves the Prediction of Pneumonia Mortality in Older Patients. J Gen Intern Med. 2018;33(4):437-44. DOl: 10.1007/s11606-017-4267-8

79. Umscheid CA, Mitchell MD, Doshi JA, Agarwal R, Williams K, Brennan PJ. Estimating the proportion of healthcare-associated infections that are reasonably preventable and the related mortality and costs. Infect Control Hosp Epidemiol. 2011;32(2):101-14. DOI: 10.1086/657912

80. Mody L. Infection control issues in older adults. Clin Geriatr Med. 2007;23(3):499-514, vi. DOI: 10.1016/j.cger.2007.02.001

81. Chami K, Gavazzi G, de Wazieres B, Lejeune B, Carrat F, Piette F, et al. Guidelines for infection control in nursing homes: a Delphi consensus web-based survey. J Hosp Infect. 2011;79(1):75-89. DOI: 


\subsection{6/j.jhin.2011.04.014}

82. Aedo-Martin D, Crego-Vita D, Garcia-Canas R, Espigares-Correa A, Sanchez-Perez C, Areta-Jimenez FJ. Periprosthetic infection in elderly patients treated with hemiarthroplasty of the hip following intracapsular fracture. Should we use antibiotic-loaded bone cement? Rev Esp Cir Ortop Traumatol. 2020;64(1):28-34. DOI: 10.1016/j.recot.2019.07.005

83. Towers S, Feng Z. Social contact patterns and control strategies for influenza in the elderly. Math Biosci. 2012;240(2):241-9. DOI: 10.1016/j.mbs.2012.07.007

84. Vila-Corcoles A, Ochoa-Gondar O, Hospital I, Ansa X, Vilanova A, Rodriguez $T$, et al. Protective effects of the 23-valent pneumococcal polysaccharide vaccine in the elderly population: the EVAN-65 study. Clin Infect Dis. 2006;43(7):860-8. D0I: 10.1086/507340

85. Makris AT, Morgan L, Gaber DJ, Richter A, Rubino JR. Effect of a comprehensive infection control program on the incidence of infections in long-term care facilities. Am J Infect Control. 2000;28(1):3-7.

86. Bouza E, Ancochea-Bermudez J, Campins M, Eiros-Bouza JM, Fargas J, Garcia Rojas A, et al. The situation of vaccines for the prevention of infections in adults: An opinion paper on the situation in Spain. Rev Esp Quimioter. 2019;32(4):333-64. PMID: 31345005

87. Gross PA, Hermogenes AW, Sacks HS, Lau J, Levandowski RA. The efficacy of influenza vaccine in elderly persons. A meta-analysis and review of the literature. Ann Intern Med. 1995;123(7):518-27. DOI: 10.7326/0003-4819-123-7-199510010-00008

88. Cunningham AL, Lal H, Kovac M, Chlibek R, Hwang SJ, Diez-Domingo J, et al. Efficacy of the Herpes Zoster Subunit Vaccine in Adults 70 Years of Age or Older. New Eng J Med. 2016;375(11):1019-32. DOI: 10.1056/NEJMoa1603800

89. Rudnick W, Liu Z, Shigayeva A, Low DE, Green K, Plevneshi A, et al. Pneumococcal vaccination programs and the burden of invasive pneumococcal disease in Ontario, Canada, 1995-2011. Vaccine. 2013;31(49):5863-71. DOI: 10.1016/j.vaccine.2013.09.049

90. Regev-Yochay G, Reisenberg K, Katzir M, Wiener-Well Y, Rahav G, Strahilevitz J, et al. Pneumococcal Meningitis in Adults after Introduction of PCV7 and PCV13, Israel, July 2009-June 2015(1). Emerg Infect Dis. 2018;24(7):1275-84. DOI: 10.3201/eid2407.170721

91. Herzig CT, Stone PW, Castle N, Pogorzelska-Maziarz M, Larson EL, Dick AW. Infection Prevention and Control Programs in US Nursing Homes: Results of a National Survey. J Am Med Dir Assoc. 2016;17(1):85-8. DOI: 10.1016/j.jamda.2015.10.017

92. Uchida $M$, Pogorzelska-Maziarz $M$, Smith PW, Larson E. Infection prevention in long-term care: a systematic review of randomized and nonrandomized trials. J Am Geriatr Soc. 2013;61(4):602-14. DOI: $10.1111 /$ jgs. 12175

93. Baldwin NS, Gilpin DF, Tunney MM, Kearney MP, Crymble L, Card-

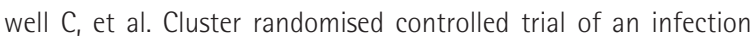
control education and training intervention programme focusing on meticillin-resistant Staphylococcus aureus in nursing homes for older people. J Hosp Infect. 2010;76(1):36-41. DOI: 10.1016/j. jhin.2010.03.006

94. Parras F, Ena J, Bouza E, Guerrero MC, Moreno S, Galvez T, et al.
Impact of an educational program for the prevention of colonization of intravascular catheters. Infect Control Hosp Epidemiol. 1994;15(4 Pt 1):239-42.

95. James D, Lopez L. Impact of a pharmacist-driven education initiative on treatment of asymptomatic bacteriuria. Am J Health Syst Pharm. 2019;76(Supplement_2):S41-s8. DOI: 10.1093/ajhp/zxy081

96. Ho HJ, Chan YY, Ibrahim MAB, Wagle AA, Wong CM, Chow A. A formative research-guided educational intervention to improve the knowledge and attitudes of seniors towards influenza and pneumococcal vaccinations. Vaccine. 2017;35(47):6367-74. DOI: 10.1016/j.vaccine.2017.10.005

97. Schneider MA. Prevention of catheter-associated urinary tract infections in patients with hip fractures through education of nurses to specific catheter protocols. Orthop Nurs. 2012;31(1):12-8. D0I: 10.1097/NOR.0b013e3182419619

98. Belmin J, Bouree P, Camus D, Guiso N, Jeandel C, Trivalle C, et al. Educational vaccine tools: the French initiative. Aging Clin Exp Res. 2009;21(3):250-3.

99. MacDonald CJ, Walton R. E-learning education solutions for caregivers in long-term care (LTC) facilities: new possibilities. Educ Health (Abingdon). 2007;20(3):85.

100. Norrby SR, Carbon C. Report of working group 3: specialist training and continuing medical education/professional development in the infection disciplines. Clin Microbiol Infect. 2005;11 Suppl 1:46-9. DOI: 10.1111/j.1469-0691.2005.01091.x

101. Grief SN, Loza JK. Guidelines for the Evaluation and Treatment of Pneumonia. Prim Care. 2018;45(3):485-503. DOI: 10.1016/j. pop.2018.04.001

102. de Cueto M, Aliaga L, Alos JI, Canut A, Los-Arcos I, Martinez JA, et al. Executive summary of the diagnosis and treatment of urinary tract infection: Guidelines of the Spanish Society of Clinical Microbiology and Infectious Diseases (SEIMC). Enferm Infecc Microbiol Clin. 2017;35(5):314-20. DOI: 10.1016/j.eimc.2016.11.005

103. Esposito S, Bonanni P, Maggi S, Tan L, Ansaldi F, Lopalco PL, et al. Recommended immunization schedules for adults: Clinical practice guidelines by the Escmid Vaccine Study Group (EVASG), European Geriatric Medicine Society (EUGMS) and the World Association for Infectious Diseases and Immunological Disorders (WAidid). Hum Vaccin Immunother. 2016;12(7):1777-94. DOI: 10.1080/21645515.2016.1150396

104. Costantino C, Vitale F. Influenza vaccination in high-risk groups: a revision of existing guidelines and rationale for an evidence-based preventive strategy. J Prevent Med Hygiene. 2016;57(1):E13-8. PMID: 27346934

105. Gonzalez-Castillo J, Martin-Sanchez FJ, Llinares P, Menendez R, Mujal $A$, Navas $E_{1}$ et al. Guidelines for the management of community-acquired pneumonia in the elderly patient. Rev Esp Quimioter. 2014;27(1):69-86. PMID: 24676248

106. Michel JP. Updated vaccine guidelines for aging and aged citizens of Europe. Expert Rev Vaccines. 2010;9(3 Suppl):7-10. DOI: 10.1586/erv. 10.27

107. Kincaid SE. Clostridium difficile-associated disease: impact of the updated SHEA/IDSA guidelines. Consult Pharm. 2010;25(12):834-6. 


\section{DOI: $10.4140 /$ TCP.n.2010.834}

108. Mader JT, Shirtliff ME, Bergquist S, Calhoun JH. Bone and joint infections in the elderly: practical treatment guidelines. Drugs Aging. 2000;16(1):67-80. DOI: 10.2165/00002512-200016010-00006

109. Jacobs LG. Fungal urinary tract infections in the elderly: treatment guidelines. Drugs Aging. 1996;8(2):89-96. DOI: 10.2165/00002512199608020-00003

110. Gore R, Parker R. Analysing power and politics in health policies and systems. Glob Public Health. 2019;14(4):481-8. DOI: 10.1080/17441692.2019.1575446

111. Campbell BW, Marrs FW, Bohmelt T, Fosdick BK, Cranmer SJ. Latent influence networks in global environmental politics. PloS One. 2019;14(3):e0213284. DOI: 10.1371/journal.pone.0213284

112. Nombela C. https://elcultural.com/La-politica-y-su-papel-en-el-conocimiento-cientifico [consultado el 22 de marzo de 2019].

113. Congreso de los Diputados. http://www.congreso.es/portal/page/ portal/Congreso/Congreso/Transparencia/InfInstit/Func [consultado el 22 de marzo de 2019].

114. Congreso de los Diputados. http://www.congreso.es/portal/page/portal/Congreso/Congreso/Organos/Comision?_pir ef73_7498063_73_1339256_1339256.next_page=/wc/detallelnformComisiones?idOrgano=325ctidLegislatura $=9$.

115. Stanford Encyclopedia of Philosophy. https://plato.stanford.edu/ entries/dewey-political/ [consultado el 22 de marzo de 2019].

116. Direct S. https://www.sciencedirect.com/. [consultado el 22 de marzo de 2019].

117. Elsevier. Clinical Key. https://www.elsevier.com/es-es/solutions/ clinicalkey.

118. Primo. Biblioteca Sanitaria online de Castilla y León. Una apuesta por la integración. http://www.expania.es/sites/default/files/Biblioteca\%20CyL.pdf.

119. Revista española de Geriatría y Gerontología. https://www.segg.es/ publicaciones/regg

120. Medes. Medicina en Español. Real Academia Española. Fundación Lilly. https://www.medes.com/Public/Home.aspx

121. PubMed. US. National Library of Medicine. Institute of Health. https://pubmed.ncbi.nlm.nih.gov/

122. Masanés $F$, Sacanella $E$, López Soto A. Infecciones en el anciano. Med Integral. 2002; 40: 423-84.

123. Díaz J, Ramiro-Fariñas D, Ayala A, Nieto P, García A, Pujol Rodriguez R. "Un perfil de las personas mayores en España, 2019. Indicadores estadísticos básicos". Madrid, Informes Envejecimiento en red nº 22, p.38.

124. Matilla Mora R. Características de la comunicación en el anciano. Terapia-ocupacionalcom. 2000; Lunes 04 de Septiembre de 2000

125. Gómez Martín MP, Díaz Veiga P, Sociedad Española de Geriatría y Gerontología. Decálogo para el buen trato a las personas mayores. https://www.segg.es/media/descargas/DECALOG0\%20BUEN\%20 TRATO.pdf

126. Aguilera Muro MJ. Adultos mayores y medios de comunicación. ¿Amigos o enemigos?. No solo arrugas.com.https://www.nosoloar-
rugas.com/smartblog/20_Adultos-mayores-y-medios-de-comunicaci\%C3\%B3n.html.

127. Lowrie F, Gibson L, Towle I, Lowrie R. A descriptive study of a novel pharmacist led health outreach service for those experiencing homelessness. Int J Pharm Pract. 2019;27(4):355-61. D0I: 10.1111/ ijpp. 12520

128. Franco Sereno MT, Perez Serrano R, Ortiz Diaz-Miguel R, Espinosa Gonzalez MC, Abdel-Hadi Alvarez H, Ambros Checa A, et al. Pharmacist Adscription To Intensive Care: Generating Synergies. Med Intensiva. 2018;42(9):534-40. D0I: 10.1016/j.medin.2018.02.006

129. McNicholl IR, Gandhi M, Hare CB, Greene M, Pierluissi E. A Pharmacist-Led Program to Evaluate and Reduce Polypharmacy and Potentially Inappropriate Prescribing in Older HIV-Positive Patients. Pharmacotherapy. 2017;37(12):1498-506. DOI: 10.1002/phar.2043

130. Wenzler E, Wang F, Goff DA, Prier B, Mellett J, Mangino JE, et al. An Automated, Pharmacist-Driven Initiative Improves Quality of Care for Staphylococcus aureus Bacteremia. Clin Infect Dis. 2017;65(2):194-200. DOI: 10.1093/cid/cix315

131. Zhang $X$, Rowan N, Pflugeisen BM, Alajbegovic S. Urine culture guided antibiotic interventions: A pharmacist driven antimicrobial stewardship effort in the ED. Am J Emerg Med. 2017;35(4):594-8. DOI: 10.1016/j.ajem.2016.12.036

132. Michal J, Henry T, Street C. Impact of a pharmacist-driven protocol to decrease proton pump inhibitor use in non-intensive care hospitalized adults. Am J Health Syst Pharm. 2016;73(17 Suppl 4):S12632. DOI: 10.2146/ajhp150519

133. Lingenfelter $E_{1}$ Drapkin $Z$, Fritz K, Youngquist $S$, Madsen $T$, Fix M. ED pharmacist monitoring of provider antibiotic selection aids appropriate treatment for outpatient UTI. Am J Emerg Med. 2016;34(8):1600-3. DOI: 10.1016/j.ajem.2016.05.076

134. Davis LC, Covey RB, Weston JS, Hu BB, Laine GA. Pharmacist-driven antimicrobial optimization in the emergency department. Am J Health Syst Pharm. 2016;73(5 Suppl 1):S49-56. DOI: 10.2146/ sp150036

135. Apisarnthanarak $A$, Lapcharoen $P$, Vanichkul $P$, Srisaeng-Ngoen $T$, Mundy LM. Design and analysis of a pharmacist-enhanced antimicrobial stewardship program in Thailand. Am J Infect Control. 2015;43(9):956-9. DOI: 10.1016/j.ajic.2015.05.011

136. Hale A, Coombes I, Stokes J, Aitken S, Clark F, Nissen L. Patient satisfaction from two studies of collaborative doctor-pharmacist prescribing in Australia. Health Expect. 2016;19(1):49-61. DOI: 10.1111/hex.12329

137. Shen J, Sun Q, Zhou X, Wei Y, Qi Y, Zhu J, et al. Pharmacist interventions on antibiotic use in inpatients with respiratory tract infections in a Chinese hospital. Int J Clin Pham. 2011;33(6):929-33. DOI: 10.1007/s11096-011-9577-z

138. Przybylski KG, Rybak MJ, Martin PR, Weingarten CM, Zaran FK, Stevenson JG, et al. A pharmacist-initiated program of intravenous to oral antibiotic conversion. Pharmacotherapy. 1997;17(2):271-6.

139. Gil Guillén M, Ribera Casado JM, Valdes y Llorca C, De Lucas Ramos P, Sánchez Purificación A, Fernandez del Palacio E, et al. Informe descriptivo "Análisis sobre de Adherencia al Tratamiento en pacientes crónicos desde el punto de vista de la farmacia". In: Observatorio de 
Adherencia Terapéutica (Grupo OAT) ES, editor. Madrid2018. p. 56.

140. McGeer A, Campbell B, Emori TG, Hierholzer WJ, Jackson MM, Nicolle $L E$, et al. Definitions of infection for surveillance in longterm care facilities. Am J Infect Control. 1991;19(1):1-7. DOI: 10.1016/0196-6553(91)90154-5

141. Stone ND, Ashraf MS, Calder J, Crnich CJ, Crossley K, Drinka PJ, et al. Surveillance definitions of infections in long-term care facilities: revisiting the McGeer criteria. Infect Control Hosp Epidemiol. 2012;33(10):965-77. DOI: 10.1086/667743

142. Consejería de Sanidad. Comunidad de Madrid. Prevención y Control de las Enfermedades Transmisibles en Atención Primaria. Gráficas Monterreina S A. 2010.

143. Consejería de Sanidad. Comunidad de Madrid. Prevención y Control de la Infección Nosocomial. Imprenta BOCM. 2008.

144. Consejo Interterritorial. Ministerio de Sanidad. Plan Nacional frente a Resistencia a Antibióticos. 2014. Disponible en: http://www.resistenciaantibioticos.es/es

145. Consejo interterritorial. Ministerios de Sanidad y Agricultura. Plan Nacional frente a la Resistencia a los Antibióticos (PRAN) 2019-2021 http://www.resistenciaantibioticos.es/es/publicaciones/plan-nacional-frente-la-resistencia-los-antibioticos-pran-2019-2021

146. Consejería de Sanidad. Comunidad de Madrid. Guía de uso de antimicrobianos en adultos con tratamiento ambulatorio. 2018. Disponible en: http://wwwcomunidadmadrid/publicacion/ref/20262.

147. Comisión Central de Política Antimicrobiana de la Comunidad de Madrid. Programa Marco para el Control de las Resistencias a los Antimicrobianos en la Comunidad de Madrid (RESISTE). 2019.

148. Organización Colegial de Enfermería. Consejo General. Resolución n 20/2017, de 14 de diciembre de 2017, por la que se ordenan determinados aspectos del ejercicio profesional enfermero en el ámbito de la prevención y control de infecciones. https://www. consejogeneralenfermeria.org/component/jdownloads/send/8normativa-colegial/690-resolucion-n-20-2017-de-14-de-diciembre-de-2017

149. Rodríguez Navas ML, Lupión Mendoza $C_{1}$ Félix Martin $M_{1}$ Torres Berdonces $\mathrm{M}$, Villar Bustos $\mathrm{C}$, et al. Documento técnico. Competencias de la Enfermera de Prevención y Control de Infecciones (EPyCl). http://www. amepreventiva.es/docamep/competencias_enfermera_EPyCl.pd

150. Rodrigues Moura da Costa Valle A, De Andrade D, Lopes de Sousa $A F$, Rodrigues Moura de Carvalho P. Infection prevention and control in households Nursing challenges and implications. Acta Paul Enferm 2016;29(2):234-9.

151. Organización Mundial de la Salud. La higiene de manos en la asistencia ambulatoria y domiciliaria y en los cuidados de larga duración. Guía de aplicación de la estrategia mundial de la OMS para la mejora de la higiene de las manos y del modelo "Los cinco momentos de la higiene de manos". https://apps.who.int/iris/handle/10665/84918

152. Lupión C, López Cortes LE, Rodriguez Baño J. Medidas de prevención de la trasmisión de organismos entre pacientes hospitalizados. Higiene de manos. Enferm Infecc Microbiol Clin 2014;32(9):603-9.

153. Huangg C, Ma W, Stack S. The hygienic efficacy of different hand-drying Methods: A Review of the Evidence. Mayo Clin Proc

\section{2; 87(8): 791-8.}

154. Best EL, Parnell P, Wilcox MH. Microbiological comparison of hand-drying methods: the potential for contamination of the environment user, and bystander. J Hosp Infect. 2014;88::199-206.

155. Sharif-Abdullah SS, Mei Chan Ch, Surat Singh SK, Shahrul Bayah K, Kwan Hoong N. The effect of chlorhexidine in reducing oral colonisation in geriatric patients: a randomised controlled trial. Singapore Med J 2016;57(5):262-6.

156. Adams J, Bartram J, Chartier Y. Organización Mundial de la Salud. Normas básicas de higiene del entorno en la atención sanitaria. Camberra (Autralia): Desing ONE. 2016.

157. Krawinkel M B. Interacción entre la nutrición y las infecciones a nivel global: una revisión. Ann Nutr Metab. 2012;61(suppl 1):19-27.

158. Segurola Gurrutxaga, Cárdenas La Granja G, Burgos Peláez R. Nutrientes e inmunidad. Nutr Clin Med 2016; X (1) 1-19.

159. Sociedad Española de Geriatria y Gerontología. Guía de buena práctica en Geriatría. Hidratación y salud. Madrid. 2011.

160. Garcia Molina A, Carbonell Baeza A, M. DF. Beneficios de la actividad física en personas mayores. Rev Int Med Cienc Activ Fis Deporte. 2010; 10(40): 556-76.

161. Ferrer Aguareles JL, Ruiz Muñoz E. Educación para la salud: infecciones y su prevención en personas mayores. Rev Rol Enfermería 2016;39(3):214-9.

162. Crawford Cohen C, Pogorzelska-Maziarz M, Herzing C, Carter $E_{1}$ Bjarnadottir $R$, Semeraro $P$, et al. Infection prevention and control in Nursing homes: a qualitative Study of decisión-making regarding isolation-based practiques. BMJ Qual Saf 2015;24 (10):630-6.

163. Grupo de vacunas de la Sociedad Española de Geriatría y Gerontología (SEGG). Recomendaciones de vacunación para adultos y mayores 2018-2019. https://www.segg.es/media/descargas/ SEGG-VACUNACION-2018-2019.pdf

164. Pujol M, Limón E. Epidemiología general de las infecciones nosocomiales. Sistemas y programas de vigilancia. Enferm Infecc Microbiol Clin 2013;31(2):108-13.

165. Gracia D. Por una cultura de la vejez. Anales de la Real Academia de Ciencias Morales y Políticas 2020; En prensa.

166. Gracia D. Valor y Precio. Editorial Triacastela. 2013. 